\title{
IFS
}

\section{UNIVERSITY RESEARCH AND THE LOCATION OF BUSINESS R\&D}

Laura Abramovsky Rupert Harrison Helen Simpson 


\title{
University Research and the Location of Business R\&D
}

\author{
Laura Abramovsky* \\ Rupert Harrison $^{*}$ \\ Helen Simpson ${ }^{\dagger}$
}

August 2006

Forthcoming in The Economic Journal

\begin{abstract}
We investigate the relationship between the location of private sector $R \& D$ labs and university research departments in Great Britain. We combine establishment-level data on R\&D activity with information on levels and changes in research quality from the Research Assessment Exercise. The strongest evidence for co-location is for pharmaceuticals R\&D, which is disproportionately located near to relevant university research, particularly 5 or $5^{*}$ rated chemistry departments. This relationship is stronger for foreign-owned labs, consistent with multinationals sourcing technology internationally. We also find some evidence for co-location with lower rated research departments in industries such as machinery and communications equipment.
\end{abstract}

Keywords: Innovation; Geography; Spillovers; Public Research

JEL classification: O3; R11; R13; I23

Acknowledgements: We would like to thank two anonymous referees and seminar participants at the University of Oxford and the 2006 RES conference for helpful comments, and the Gatsby Charitable Foundation, the ESRC Centre for the Microeconomic Analysis of Public Policy at the IFS, and AIM for financial support for this research. This work contains statistical data from ONS, which is Crown copyright and reproduced with the permission of the controller of HMSO and Queen's Printer for Scotland. The use of the ONS statistical data in this work does not imply the endorsement of the ONS in relation to the interpretation or analysis of the statistical data. All errors are the responsibility of the authors.

Correspondence: labramovsky@ifs.org.uk (corresponding author), hsimpson@ifs.org.uk

${ }^{*}$ IFS and University College London; ${ }^{\dagger}$ IFS and Nuffield College, University of Oxford 


\section{Executive Summary}

This paper provides the first comprehensive evidence on the extent to which businesssector R\&D activity is located in the vicinity of high quality university research departments in Great Britain. We exploit rich data on R\&D activity in specific product groups at the establishment level, together with novel measures of the presence and quality of university research in relevant subject areas from the Research Assessment Exercise (RAE), at a fine level of geographic disaggregation. The findings shed new light on the links between public research and business $R \& D$ and the role of geographic proximity in public-private sector interactions, which are topical policy issues in the UK and elsewhere.

The strongest evidence for co-location is for pharmaceuticals $R \& D$, which is disproportionately located near to relevant university research, particularly high quality chemistry departments. This relationship is stronger for foreign-owned labs, consistent with multinationals sourcing technology internationally and confirming the importance of world-class centres of research for attracting increasingly footloose R\&D investment. We also find some evidence for co-location with lower quality rated research departments in industries such as machinery and communications equipment, which raises the possibility that firms may benefit both from proximity to frontier basic university research and from more applied public sector research activity. The latter may be measured as low quality research for the purposes of the RAE and funding allocations, but our results suggest that it may play a role in some areas of technology transfer and even in attracting foreign-owned R\&D investment. However, without further supporting evidence on the underlying economic mechanisms at work, it is difficult to make specific policy recommendations based on these results. 


\section{Introduction}

This paper provides the first comprehensive evidence on the extent to which businesssector R\&D activity is located in the vicinity of high quality university research departments in Great Britain. We exploit rich data on R\&D activity in specific product groups at the establishment level, together with novel measures of the presence and quality of university research in relevant subject areas at a fine level of geographic disaggregation. The findings shed new light on the links between public research and business R\&D and the role of geographic proximity in public-private sector interactions, which are topical policy issues in the UK and elsewhere.

Our empirical approach relates the location pattern of private sector R\&D establishments to the presence of nearby relevant university research departments. We use data from the UK Research Assessment Exercise (RAE) to separate research departments into those rated 5 or $5^{*}$ by the RAE, which are deemed to perform world-class cutting edge research, and those rated 4 or below. Figures 1 and 2 illustrate graphically the basic relationship underlying our empirical strategy. Figure 1 shows the population distribution of R\&Dperforming establishments for the six product groups we consider across UK postcode areas in 2003, while Figure 2 shows the equivalent distribution of 5 and $5^{*}$ university departments assigned as relevant for those product groups, using information from the 2001 RAE. ${ }^{1}$ Postcode areas with higher numbers of R\&D-performing establishments in Figure 1 or 5 and $5^{*}$ relevant departments in Figure 2 are represented by darker shaded areas. Comparison of Figures 1 and 2 shows a clear positive correlation between the location of R\&D-performing establishments in 2003 and the presence of high quality relevant university research departments.

[Figures 1 and 2 here] 
The correlation displayed in Figures 1 and 2 is not sufficient to infer any causal relationship between the location of high quality university research and the distribution of business R\&D. In our empirical results we use a number of strategies in an attempt to separately identify the impact of university research from other observed and unobserved heterogeneity across locations. First, in the cross section we include controls for a range of other observable factors which may influence the location of business R\&D, including measures of the agglomeration of economic activity, the skills of the local labour force, and the location of science parks. Second, we relate the entry pattern of R\&D-performing establishments over 2001-2003 to the change in the presence and quality of university research departments between the 1996 and 2001 RAEs. This should control for unobserved heterogeneity across locations that is correlated with the level of university research quality.

We find evidence for co-location of business $R \& D$ and university research departments that is robust to controlling for various sources of observed and unobserved heterogeneity. Our most consistent evidence is for the pharmaceuticals industry, where we find a positive and significant relationship between the location of private sector R\&D establishments and both lower and high-quality chemistry departments. This relationship is strongest with respect to departments rated 5 or $5^{*}$, and is even stronger when we restrict the analysis to foreign-owned R\&D establishments which are likely to be highly geographically mobile. In the chemicals industry (excluding pharmaceuticals) we find a robust significant effect of the presence of materials science departments rated 5 or $5^{*}$, while in industries such as machinery and communications equipment we also find some evidence for co-location near to relevant departments rated 4 or below.

What economic mechanisms might drive the co-location of business $\mathrm{R} \& \mathrm{D}$ and relevant public sector research? Survey-based empirical evidence shows that the research base is an 
important source of knowledge for businesses. ${ }^{2}$ There are a number of routes through which university research might generate beneficial knowledge spillovers. Geographic proximity is likely to be crucial if the primary mechanism through which such knowledge is transferred is through direct personal interactions. However, if the main mechanism is through codified knowledge such as journal publications then geographic proximity may be less relevant. As well as pure spillovers, knowledge may also be transferred through formal collaboration agreements, spin-out companies or consultancy. In addition to providing information, university research departments may also support business R\&D through the supply of trained post-graduate research scientists.

In the context of these different ways in which businesses may benefit from proximity to the public research base, the co-location of business $\mathrm{R} \& \mathrm{D}$ and relevant research departments raises potentially interesting implications for policy, particularly for the evaluation and funding of university research. However, without further information on the exact mechanisms at work it is difficult to make specific policy recommendations. In each of the examples described above there is varying potential for market failures, and the implications for the direction of public funding and the design of incentives for scientists and university administrators may be different. The routes through which university research is transferred to businesses, and the ways in which university and private sector scientists work together, may also differ across industries, and may depend on the nature of the research being undertaken, for example whether it is basic or applied. Our results thus provide a useful input into the policy process, but should not be taken in isolation as supporting a particular direction of policy in this area.

This paper is part of an extensive empirical literature on innovation and location that studies the existence of geographically mediated spillovers and considers location as a determinant of innovative activity. The literature that investigates the effects of university 
research on business innovation activity is particularly relevant to our research. ${ }^{3}$ For example, Jaffe (1989) looked at the existence of spillovers from university research to commercial innovation using state-level time-series data on firms' patenting activity, industrial $R \& D$ expenditure and university $R \& D$ expenditure for the US. He finds a significant direct effect of university research on corporate patents in some specific research areas, and an indirect effect on the local production of corporate patents by fostering industrial $R \& D$ spending. These results indicate that knowledge spillovers increase with geographic proximity and hence that innovative activity might be expected to be more concentrated in areas where knowledge inputs such as the scale or quality of university research are higher. Harhoff (1999) investigates the relationship between entry and regional employment structure. He finds a positive relationship between new firm formation in high-tech sectors and the presence of university and other research scientists in a location.

The fact that our strongest results are for pharmaceuticals is also consistent with findings elsewhere in the literature. For example, Branstetter and Ogura (2005) examine the large increase in the propensity of patents in the US to cite academic science over the 1990s. They find that the nature of inventive activity changed over the period, with an increased emphasis on the use of knowledge created in universities. However, they also find that citations to academic science are heavily concentrated in bioscience-related innovations.

The remainder of the paper is structured as follows. The next section provides some information on recent policy developments in the UK. Section 3 provides a description of the data. Section 4 discusses our empirical strategy and shows our main results and section 5 concludes. 


\section{Policy Background}

The UK government has recently commissioned two reviews into innovation policy: the Lambert Review of Business-University Collaboration (2003) and the Department of Trade and Industry (DTI) Innovation Report (2003). Both stressed the importance of the interaction between research institutions and businesses and the role of geographic innovative clusters in improving the UK's innovation performance. The Lambert Review investigated specifically the extent and benefits of collaboration between businesses and university research departments and stressed the importance of proximity to universities for firms to access to research ideas. The final report made a number of recommendations aimed at both universities and business, including recommendations for greater government support for collaborative activities through DTI schemes such as LINK and Knowledge Transfer Partnerships. The economic rationale for such schemes usually appeals to the presence of spillovers and/or coordination failures that would result in a sub-optimal level of collaboration activity and knowledge transfer in the absence of intervention. The report also made recommendations for the way the funding system for research should operate to enhance transfer knowledge from universities to businesses.

Public funding for research in Higher Education institutions in Great Britain is administered under a dual support system. In this system the Higher Education Funding Councils (HEFC) provide block grant funding to support research infrastructure and enable institutions to undertake ground-breaking research. ${ }^{4}$ The HEFC funding constitutes the first stream of funding for universities, most of which is allocated according to past research performance determined by the Research Assessment Exercise. Top rated departments receive a funding weight over three times higher than lower quality research departments. ${ }^{5}$ The definition of research for the purpose of the RAE includes work of direct relevance to the needs of commerce and industry. However, there are concerns that in practice the 
assessment panels that determine the quality of the research tend to rely on more academic benchmarks, such as output in important journals, than world-class research in collaboration with businesses. ${ }^{6}$ One of the recent initiatives to increase the diffusion of research findings from universities into the economy has been the introduction of the Higher Education Innovation Fund (HEIF), which supports Higher Education institutions in knowledge transfer activities with business, public sector organisations and the wider community. However, its contribution to university funding is modest compared to the HEFC financial support.

\section{Data and Descriptive Statistics}

\subsection{Business Sector R\&D Activity}

We use the Office for National Statistics (ONS) establishment-level UK Business Enterprise Research and Development (BERD) data, for the period 2000-2003, to construct measures of business sector R\&D activity. The establishment-level BERD data provide information on the population of establishments performing intramural $R \& D$ in Great Britain. Each establishment’s full postcode, industry and ownership status are registered. ${ }^{7}$

The ONS collects more detailed information about R\&D expenditure at the establishment level by surveying a sample of establishments drawn from this population. The sample includes a census of large R\&D-performing establishments and a stratified sample of the remainder of the population. Large R\&D-doers answer detailed questions on the type of R\&D carried out (e.g. intramural, extramural, basic, applied or experimental), broken down by the product group for which the R\&D is being carried out, for example pharmaceuticals. $^{8}$ The rest of the sample receives a less detailed shorter form to report on total R\&D expenditure and employment. 
Because not all establishments are surveyed each year, in our analysis we rely mainly on basic information available for the whole population of R\&D-doers rather than on the more detailed information on the precise type of $R \& D$ conducted, which is only reported by large R\&D-performing establishments. ${ }^{9}$ We use information on the location of the population of establishments carrying out intramural $R \& D$ and information on ownership status to investigate where foreign-owned firms are carrying out R\&D within Great Britain. We use one additional piece of information that is not reported for all establishments - the product group for which R\&D is being conducted - which we discuss further below.

Using the population information we construct measures of the presence of business sector R\&D activity at the postcode area level, defined by the first two letters of the full postcode, for example "BS" for Bristol. We aggregate all establishments located in central London (E, EC, N, NW, S, SW, W, WC) into a single postcode area. ${ }^{10}$ This gives us 111 postcode areas. We use postcode areas as the unit of observation because they are constructed around centres of economic activity (around cities and towns) rather than on administrative grounds. This is not the case for the central London postcodes and hence we aggregate these areas. Some postcode areas are dominated by large cities and agglomerations of economic activity, and so we pay careful attention in the empirical results to controlling for a range of other factors that may determine the concentration of $R \& D$ establishments in a particular postcode area.

We investigate the location of R\&D activity related to different product groups separately. We construct two measures for each postcode area for each product group. First, our main measure is a count measure of the average number of establishments carrying out intramural R\&D expenditure over the period 2000 to 2003, and second a count of the total number of greenfield entrants carrying out intramural R\&D over the three years 2001 to $2003 .{ }^{11}$ We focus on six product groups that account for $54 \%$ of total intramural R\&D in 
2003: pharmaceuticals; chemicals; machinery; electrical machinery; TV, radio and communication equipment; and motor vehicles.

Product group information is not collected for smaller, sampled R\&D-performing establishments and for non-sampled establishments. However, each company's Standard Industrial Classification (SIC) code is known and the ONS assumes that R\&D expenditure is for the product group corresponding to that SIC category. For example, R\&D being carried out in a small firm that operates in the chemicals industry will be assigned to the chemicals product group. This results in a large number of small $\mathrm{R} \& \mathrm{D}$ establishments being classified as $R \& D$ services providers, whereas it is very likely that they do $R \& D$ for other product groups. This means that in our main analysis we may not be capturing the locations of all R\&D activity devoted to the six product groups, (although we will be capturing the locations of establishments accounting for the vast majority of expenditure within these product groups). As an additional exercise we thus look separately at the pattern of location of R\&D services labs around university research departments.

\subsection{Measuring University Research Quality}

In our main analysis we use the results of the most recent Research Assessment Exercise in 2001 to map the presence and the quality of research carried out by universities, and their specific research departments in Great Britain. To look at changes over time in RAE scores we also use data from the previous RAE in 1996. The Higher Education Funding Council for England (HEFCE) collects the RAE, with the primary purpose being to produce ratings of research quality used to allocate the main grant for research use among universities. Each university submits research activity for assessment on all or some fraction of the research staff in departments of their choice. In 2001, there were 2,598 submissions by 173 universities to the RAE on 68 subject research areas in the UK. ${ }^{12}$ Each department submission is rated within a scale of $1,2,3,4,5$ and $5 *$. The higher the number in the scale 
the higher the department's research is rated. In some cases, departments in the same location from the same university chose to send more than one submission. We use the maximum rating achieved by the multiple submissions, leaving us with 2,515 submissions. Once we exclude Northern Ireland we have a total of 2,448 research departments.

Using the RAE information we first construct a variable to indicate the rating attached to the university as a whole as an average of the ratings of that university's submitted departments weighted by the number of researchers submitted for assessment, (we turn the rating $5^{*}$ into 6 to do this). We then construct measures of university presence, (the total count of universities), and the average quality of university research at the postcode area level. We treat all departments belonging to a university as located within the same postcode area, given by the postcode of the central administrative office.

We use information on each departmental submission to construct a measure of the presence and quality of relevant research activity for each of the six product groups in each location. To define the relevancy of the research areas we use the 1994 Carnegie Mellon Survey (CMS) results that reports for each industry the importance of the following ten research fields: biology; chemistry; physics; computer science; materials science; medical and health science; chemical engineering; electrical engineering; mechanical engineering; and mathematics. ${ }^{13}$ We consider a field to be relevant for a product group if it was rated moderately or very important (a score of at least three on a four-point scale) for the corresponding industry by over $50 \%$ of the survey respondents. We assign each of the RAE departments to the ten CMS fields, as shown in Table A.1 in the Appendix. ${ }^{14}$

Then, for each research field in each postcode area we construct two variables that combine the number and research quality of the university departments corresponding to that field: the number of departments belonging to that field rated 5 and $5 *$; and the number of departments rated 4 or below. It is worth noting that the departments are rated based on 
their research quality but not necessarily on how well they interact with businesses, which might be important for a business deciding where to locate its R\&D activity. Further, although the most recent RAE was carried out in 2001, the research submitted for assessment was carried out in the five years to the end of 2000 .

In our analysis using new entrants we construct measures of the change in the number of 5 and 5* departments and the change in the number of departments rated 4 or below in each postcode area and research field using information from both the 1996 and 2001 RAEs. This allows us to control for any unobserved heterogeneity across areas that may be correlated with the level of relevant research quality.

\subsection{Control Variables}

We include a number of further area-level variables in our main analysis. We include three variables to capture the size and industrial structure of each area. First, we use the log of total manufacturing employment in the postcode area to control for the scale of each area and potential agglomeration externalities. Some of the highest values of this variable include large urban areas such as Manchester, Newcastle and Birmingham, and other postcode areas in the Midlands. Second, we include an index of the diversification of manufacturing employment to control for potential urbanisation economies. ${ }^{15}$ Third, we use the percentage of total manufacturing employment in the postcode area that is in the relevant industry, (i.e. the industry corresponding to each product group), to control for potential industry localisation externalities, and the co-location of $\mathrm{R} \& \mathrm{D}$ facilities with production. ${ }^{16}$ This final measure varies at the industry-area level. All three measures are constructed using the ONS plant-level ABI-ARD population data for the year 2000.

We also include a control for the skill composition of the workforce which can determine the types of firms operating in the area and also contribute to the innovation process and to 
knowledge spillovers. ${ }^{17}$ We use the percentage of the economically active population in that postcode area that are qualified to degree equivalent or above (Level 4), constructed from official labour market statistics for local and national areas. ${ }^{18}$ We also include the log of the total number of research students in all departments in the postcode area rated 4 or below and the log of total research students in all departments in the area rated 5 or $5 *$ to capture the potential contribution of local universities to the local labour market.

We include a range of further measures in our robustness checks. First we include a measure of the percentage of the working population who are employed as scientific and technical professionals or associate professionals from the 2001 Census, as a further control for the characteristics of the local labour force. We use this only as a robustness check since these data are not available for Scotland. Finally we include measures of the presence of science parks in each postcode area from the UK Science Park Association (UKSPA). To the extent that science parks are located near to high quality research departments this is likely to make it more difficult to separately identify significant effects of proximity to relevant research.

\subsection{Descriptive Statistics}

Table 1 breaks down total intramural R\&D expenditure and counts of R\&D-doing establishments by product group for Great Britain. In 2003, total business intramural R\&D expenditure in Great Britain amounted to approximately $£ 13.6$ billion in nominal terms. Looking at the R\&D expenditure distribution across product groups, the second column of Table 1 indicates that business R\&D expenditure is highly concentrated: the seven product groups shown account for $66 \%$ of total business $R \& D$ expenditure. $R \& D$ expenditure in pharmaceutical products is the most important, accounting for a quarter of the total, followed by aerospace with $12 \%$ and motor vehicles with $9 \% .{ }^{19}$ 
In 2003, 10,492 establishments are classified as performing intramural R\&D. The distribution of establishments is much less concentrated across products than the distribution of expenditure, the same seven products account for less than $25 \%$ of total establishments doing R\&D. This suggests that a small number of establishments account for a large share of total business $R \& D$ expenditure. This is in line with the fact that large firms account for around $75 \%$ of total R\&D performed in UK businesses, (National Statistics, 2005). We also look at the location pattern of specialised small R\&D labs, operating in natural sciences and engineering. These comprise a further $15 \%$ of establishments.

[Table 1 here]

Our main analysis centres on the location of $R \& D$ facilities and we focus on count measures of R\&D-doing establishments in each location rather than total expenditure. This places equal weight on large and small establishments, and means that we capture small spin-out commercial ventures from universities and other small R\&D start-ups which may be important in capturing any co-location of private sector R\&D facilities and university research departments in our data. Given that the distribution of R\&D across establishments is extremely skewed as discussed above, results using total expenditure would be dominated by small number of very large establishments.

In 2003, R\&D activity carried out by foreign-owned establishments represented $45 \%$ of total intramural $R \& D$ expenditure and $15 \%$ of the total number of establishments. $R \& D$ expenditure carried out by foreign-owned establishments is more concentrated in motor vehicles, TV, radio and communication equipment and machinery and slightly less concentrated in pharmaceuticals and aerospace compared to total expenditure. Regarding the distribution of establishments across product groups, foreign-owned establishments are 
more concentrated compared to all R\&D-doing establishments in Great Britain: the seven product groups account for $41 \%$ of foreign-owned R\&D-doing establishments.

Table 2 provides descriptive information on the variables used in our main analysis. The first three rows show general university characteristics: $64 \%$ of the postcode areas have at least one university, which means that 40 postcode areas do not have a university at all. On average, postcode areas have one and a half universities but there is variation across areas, 42 being the greatest number of universities found in one single area (inner London). ${ }^{20}$ Next we present descriptive statistics on the specific relevant departments by rating. The figures show that the relevant departments are often concentrated in few postcode areas and that departments rated 5 and $5 *$ are even more concentrated. Medical departments rated 4 or below are present in the largest number of postcodes, with only 66 out of 111 postcode areas having none, while materials science departments rated 5 or $5^{*}$ are present in the fewest number of postcodes, with 104 postcode areas having none.

[Table 2 here]

In the robustness section we use measures of the change in the number of relevant departments between the 1996 and 2001 RAE. Table A.3 in the Appendix shows descriptive statistics for changes over this period in all the of the university variables. There is a general decrease in the number of departments rated 4 or below and a corresponding increase in the number rated 5 or 5*. This may partly represent "grade inflation”, and to the extent that these increases do not represent genuine changes in research quality this will tend to make it harder to identify significant effects of changes in the number of relevant departments. In addition, the number of postcode areas with no variation is generally higher than was the case in levels. This will also tend to make it harder to identify significant effects. 
Descriptive statistics on the number of $R \& D$ labs by product group and ownership, our dependent variables, are displayed with the regression results in the bottom row of each table in section 3.

\section{Empirical Strategy and Findings}

This section outlines our empirical strategy and then discusses our findings. The motivation for our empirical approach depends on the underlying model of firm behaviour in mind. Our data cover a very heterogeneous set of $R \& D$ establishments. Some, in particular those owned by multinational firms, are likely to be highly geographically mobile. For these firms the relevant decision is whether locating in close proximity to a university is likely to increase their $R \& D$ productivity, or lower their costs of carrying out $R \& D$, relative to an alternative location. In this case evidence of co-location with university research departments could indicate that geographic proximity is important to capitalise on potentially cost-reducing knowledge spillovers.

Other establishments in our data will be small start-ups. Here the relevant decision might be whether an individual chooses to set up a new business in the area where he or she lives or works, rather than where to set up a new business. Hence, in this case a positive association with particular research departments is potentially in line with individuals in those departments having a higher propensity to set up their own commercial ventures.

Given this potential heterogeneity in the underlying decision process, we estimate a negative binomial count data model in order to capture the general pattern of location outcomes in our data, rather than specify a more precise model for such a heterogeneous set of firms. $^{21,22}$ In our main specification we investigate the cross-section relationship between the location of R\&D establishments and the quality of the research base. We look at each product group separately, as it is very likely that the importance of university research and 
specific university research departments for the location of private sector $R \& D$ varies across products. We estimate the relationship between a count of establishments (an average over the years 2000 to 2003) reporting a positive amount of intramural R\&D expenditure in a postcode area in each product group and the presence and quality of university research departments that are considered to be relevant for that specific type of R\&D. Thus the unit of observation is the postcode area, and we look across 111 postcode areas in which either R\&D establishments or universities are located. The basic specification is as follows:

E(establishments $\left.{ }_{i j}\right)=\exp \left(\mathbf{R} \mathbf{L}_{\mathrm{ij}}^{\prime} \boldsymbol{\alpha}_{\mathbf{1 i}}+\mathbf{R} \mathbf{H}_{\mathrm{ij}}^{\prime} \boldsymbol{\alpha}_{\mathbf{2 i}}+\mathbf{Z}_{\mathbf{j}}^{\prime} \boldsymbol{\gamma}_{\mathbf{i}}+\mathbf{X}_{\mathbf{i j}}^{\prime} \boldsymbol{\beta}_{\mathbf{i}}\right)$

where the dependent variable is the number of $R \& D$ establishments in product group $i$ in postcode area $j$. Our main explanatory variables are vectors of the number of departments rated 4 and below, $\boldsymbol{R} \boldsymbol{L}_{i \mathbf{j}}$, and the number of departments rated 5 and 5*, $\boldsymbol{R} \boldsymbol{H}_{i j}$, in each of the different research fields relevant for product group $i$, in postcode area $j$. We run this specification separately for each product group $i$, so we allow the coefficients to vary across product groups. Each regression also includes a vector of postcode area level variables $Z_{j}$ to account for university characteristics - a dummy variable for the presence of a university, a count of the number of universities, a measure of the overall average quality of university research and the log of the total number of research students across all departments in 1-4 and 5 and $5 *$ rated departments, plus a vector $\boldsymbol{X}_{\boldsymbol{i j}}$ of other relevant industrial and labour market characteristics. The variables capturing the presence and quality of university research, constructed from the RAE data, are officially dated 2001, but it is important to note that they refer to research outputs produced over the five years to the end of 2000. The remaining controls are also dated 2000. 
While we attempt to control for other factors that may affect the location of business research and development the results from the above specification should be interpreted as correlations rather than causal relationships. For example, common unobserved factors may determine both the quality of research departments and the location of $R \& D$, or there may be reverse causation from the location of business $R \& D$ to the quality of research departments. In general these effects are likely to bias the results towards finding evidence for the co-location of business R\&D and relevant university research.

We conduct some further exercises to try and address the issue of correlated unobserved heterogeneity across areas. First we experiment with adding a range of further control variables as described in section 2.3. Second we estimate an alternative specification which looks at the relationship between a count measure of greenfield entrants over the period 2001 to 2003 and changes in the university research quality variables described above between the 1996 and 2001 RAEs. The resulting specification is as follows:

$E\left(\right.$ entrants $\left._{i j t}\right)=\exp \left(\Delta \mathbf{R L}_{\mathrm{ijt}-\mathbf{1}}^{\prime} \boldsymbol{\alpha}_{\mathbf{1 i}}+\Delta \mathbf{R} \mathbf{H}_{\mathrm{ijt}-\mathbf{1}}^{\prime} \boldsymbol{\alpha}_{\mathbf{2 i}}+\Delta \mathbf{Z}_{\mathbf{j t}-\mathbf{1}}^{\prime} \boldsymbol{\gamma}_{\mathbf{i}}+\alpha_{3 i} \mathbf{N}_{\mathrm{ijt}-\mathbf{1}}+\mathbf{X}_{\mathrm{ijt}-\mathbf{1}}^{\prime} \boldsymbol{\beta}_{\mathbf{i}}\right)$

where the dependent variable is now the number of greenfield $R \& D$ entrants over the period 2001 to 2003, the counts of relevant departments (and other variables relating to the presence and quality of universities) are differences over the previous period between RAE 1996 and $2001,^{23}$ and $\boldsymbol{N}_{\boldsymbol{i j t}-\mathbf{1}}$ is the number of pre-existing R\&D establishments in the product group in that area in 2000. Differencing the RAE variables accounts for any unobserved heterogeneity across areas that may be correlated with the level of relevant research quality but not its change. Including the number of pre-existing establishments in 2000 should help to control for any residual unobserved heterogeneity in the attractiveness of the area for R\&D activity in the relevant product group during the period up until 2000 . 
The remaining controls capture aspects of agglomeration and the quality of the labour force as before. $^{24}$

We present all the results in the form of incidence rate ratios. An incidence rate ratio greater than 1 corresponds to a positive coefficient, and an incidence rate below one corresponds to a negative coefficient in the negative binomial model. For ease of exposition, the coefficients displayed in the tables are the incidence rate ratios minus 1 . For example, an incidence rate ratio of 1.3 is displayed as 0.3 and means that for every one-unit increase in the explanatory variable in an area, there is a $30 \%$ increase in the expected number of $R \& D$ doing establishments in that area. An incidence rate of 0.65 is displayed as -0.35 and means that for every one-unit increase in the explanatory variable, there is a $35 \%$ decrease in the expected number of R\&D-performing establishments. We report z-statistics in parentheses, and indicate significant results at the $1 \%$ and $5 \%$ levels. Each table also presents information on the dependent variable's mean, standard error, maximum and the number of postcode areas where the count of R\&D-doing establishments is zero.

\subsection{Location of Existing Establishments}

Table 3 shows the results of the regressions for existing establishments. For each product group we show the results for all establishments and foreign-owned establishments separately. Conditional on the presence of departments in relevant fields, the number of R\&D establishments appears not to be correlated with the presence of universities in general, the number of universities and overall research quality. One exception is electrical machinery, where R\&D labs are slightly less likely to be located in areas that have more universities, although the effect of the dummy for the presence of a university is positive.

In all cases the coefficient on the log of manufacturing employment in the area is positive and highly significant as expected, and in all but one case the coefficient on our measure of 
area specialisation in the relevant industry is also positive and significant. In the case of motor vehicles the diversification index also enters positively and significantly; taken together with the other measures of industrial activity this indicates that $R \& D$ establishments in this product group are likely to be located close to large centres of manufacturing activity in both their own and other sectors. The proportion of the population who have Level 4 skills or above enters positively and significantly in some sectors with the effect being largest in pharmaceuticals.

Regarding the presence of specific university research fields rated 4 and below, there are a number of positive coefficients that are significant at the $5 \%$ or $1 \%$ level, particularly for foreign-owned establishments. Given the number of hypotheses being tested in Table 3 we would expect to find some significant effects merely by chance. However, 7 out of the 56 estimated effects of the presence of specific departments in Table 3 are significant at the $1 \%$ level, indicating that the results are significantly stronger than would be expected by chance.

For the pharmaceuticals sector both all establishments and foreign-owned establishments are more likely to be located in areas with chemistry departments rated 4 or below, compared to areas without a 1-4 rated department. The size of the coefficient in the first column suggests that an additional department in a postcode area is associated with a $42 \%$ increase in the expected number of establishments. On average a postcode area has between one and two establishments performing R\&D in pharmaceuticals, although the distribution is skewed, with a maximum of 12, and 40 out of 111 postcode areas having none at all. Note that an increase of one relevant department rated 4 or below is a large change - as shown in Table 2, the average number of chemistry departments rated 4 or below across all 111 postcode areas is only 0.2. 
Along similar lines, an additional materials science department rated 4 or below in a postcode area is associated with a $52 \%$ increase in the expected number of foreign-owned establishments in machinery, and an extra electrical engineering department rated 4 or below is associated with around a $69 \%$ increase in the expected number of foreign-owned establishments in electrical machinery. All of these results seem fairly intuitive, and the fact that these departments are not rated as carrying out world-class research suggests that a positive relationship with the presence of foreign $R \& D$ establishments may be driven by other factors such as technical support, consulting, or flows of students and personnel.

It is interesting to note that the number of mechanical engineering departments rated 4 or below enters positively and significantly for machinery, TV and radio equipment and motor vehicles if we drop the controls for manufacturing employment and the number of research students. This suggests that the location of R\&D establishments in these product groups is correlated with the presence of these departments, but that they also tend to be located in areas where there is a relatively large amount of manufacturing employment and/or a large number of research students (across all departments).

Turning to the presence of departments rated 5 or $5 *$, the only consistent results are for pharmaceuticals and chemicals. In particular, the number of chemistry departments rated 5 or 5* enters positively and significantly for pharmaceuticals, particularly for foreign-owned establishments. ${ }^{25}$ The effects appear to be very large, but it is important to remember that the average number of such departments in a postcode area is only about 0.2 as shown in Table 2, so an increase of one is a large change. For foreign establishments there is also a smaller positive and significant impact of the number of medical departments rated 5 or $5 *$. Both of these results are consistent with the proposition that foreign-owned R\&D establishments in pharmaceuticals are particularly likely to locate near to centres of relevant cutting edge research in order to source technology or expertise. ${ }^{26}$ This is 
particularly interesting given that pharmaceuticals accounts for about a quarter of all business R\&D expenditure in Great Britain, and that foreign-owned establishments account for around a third of R\&D expenditure within the sector (see Griffith et al., 2004).

Surprisingly, we also find a significant negative impact of the presence of highly rated biology departments on the expected number of establishments doing R\&D in pharmaceuticals. While the unconditional correlation between the location of these establishments and highly rated biology departments is positive but insignificant, the estimated relationship becomes negative once we condition on the other variables. There is a strong positive correlation between the presence of highly rated chemistry and biology departments, (areas with a 5 or $5^{*}$ chemistry department always also have a 5 or $5^{*}$ rated biology department, but not vice versa), thus postcode areas with highly rated biology departments but not highly rated chemistry departments are particularly unlikely to contain establishments doing pharmaceuticals R\&D. One possible interpretation is that this may reflect something about the subject focus of biology departments that are not located close to highly rated chemistry departments.

[Table 3 here]

The only other positive result for departments rated 5 or $5^{*}$ is that establishments doing R\&D in chemicals are significantly more likely to be located in areas with more highly rated materials science departments. This result appears to driven by domestically-owned rather than foreign establishments.

\subsection{Robustness}

In this section we check the robustness of our strongest set of results, for all establishments in the pharmaceuticals sector, to a range of alternative specifications. The results are shown in Table 4, where only the coefficients on the numbers of relevant departments are reported 
for ease of presentation. The first column repeats the results in the first column of Table 3, except that London is dropped from the sample. The results are almost identical, although the coefficient on the number of chemistry departments rated 4 or below becomes just insignificant at the 5\% level. Column (2) also repeats the specification from the first column of Table 3 except that we include a set of region dummies, so that the results are identified from variation within broad regions. Again the results are extremely similar, and some of the region dummies enter significantly, with negative coefficients on all regions relative to southern England.

Column (3) includes a measure of the percentage of the working population who are employed as scientific and technical professionals or associate professionals from the 2001 Census, as a further control for the characteristics of the local labour force. These data are not available for Scotland and so we lose 7 observations. The variable enters strongly positively and significantly, with a one standard deviation increase of $0.5 p p t$ in the working population employed as scientific and technical professionals or associate professionals being associated with about a 75\% increase in the expected number of establishments performing R\&D in pharmaceuticals. ${ }^{27}$ Interestingly the coefficient on the proportion of the population having Level 4 skills or above now becomes insignificant, with a coefficient (zstatistic) of 0.050 (1.47). Most importantly however, the main results are not significantly affected, and in fact the number of medical departments rated 4 or below now enters positively and significantly.

[Table 4 here]

Columns (4) and (5) control for the presence of science parks. Many university spin-outs and science-based businesses are located in science parks close to universities, and this may play an important role in location decisions. Column (4) includes a zero-one dummy for the presence of a science park in the postcode area, which enters positively but is not 
quite significant at the $5 \%$ level. The main results for departments rated 5 or $5 *$ are not significantly affected, but the number of chemistry departments rated 4 or below becomes just insignificant at the $5 \%$ level. Column (5) instead includes the absolute number of science parks in the postcode area, and this enters positively and significantly, with an additional science park associated with a $29 \%$ increase in the expected number of $R \& D$ establishments. Interestingly, the effect of the number of chemistry departments rated 5 or 5* now becomes much smaller and insignificant, suggesting that the presence of science parks may be driving the positive effect of highly rated chemistry departments. This does not necessarily suggest that highly rated chemistry departments are not relevant for location decisions, since the location of science parks is itself endogenous. Instead these results suggest that science parks located close to highly rated chemistry departments are positively correlated with the location of establishments performing $R \& D$ in pharmaceuticals. $^{28}$

We also investigated replacing the number of relevant departments rated 4 or below and 5 or $5^{*}$ with the number of submitted researchers in relevant departments and the number of research students (not reported). While the signs of the coefficients were similar to the results using simply the number of departments, they were not significant, for example the coefficient (z-statistic) on the number of active researchers in chemistry departments rated 5 or $5^{*}$ was 0.021 (1.55). This suggests that it is the presence of relevant departments, rather than their size or contribution to the local labour market, that is most associated with the location of R\&D establishments in pharmaceuticals.

Finally, column (6) replaces the dependent variable with a count of the number $R \& D$ establishments recorded as being in the R\&D services industry. ${ }^{29}$ As mentioned in section 2.1, there are some small, specialised $R \& D$ services labs for which the data does not specify the product group for which they are doing R\&D (the product group is assumed to 
be the same as the industry in which they operate, $R \& D$ services), making it difficult to know which fields of academic research are likely to be relevant for their activities. Of the 1,696 labs recorded as being in the $R \& D$ services industry in 2003, 112 do provide information about the product group for which they are doing R\&D. Of these just over $50 \%$ report that they are performing $R \& D$ in pharmaceuticals, with about a further $25 \%$ spread across the other product groups that we consider, and the remaining $25 \%$ in other product groups. For this reason we investigate whether the location of R\&D services labs is related to the presence of research departments that are relevant to the pharmaceuticals industry.

The results in column (6) of Table 4 provide some evidence that the location pattern of R\&D services labs is related to the presence of relevant departments in a similar way to the location of establishments performing R\&D in pharmaceuticals, with a significant positive effect of the number of highly rated chemistry departments, as well as a positive effect of highly rated medical departments and a negative effect of medical departments rated 4 or below. However, these results generally become insignificant if we include counts of all other potentially relevant departments, although the number of highly rated medical departments remains significant at the $10 \%$ level.

\subsection{Location of Entrants}

Even after controlling for a wide range of observable factors it is possible that the results in Tables 3 and 4 are affected by unobserved heterogeneity across areas that is correlated with the level of relevant research quality. In order to address this, Table 5 contains our results for the relationship between the number of entrants over 2001-2003, and the change in the number of university departments rated 4 or below, and 5 or $5^{*}$, between the 1996 and 2001 RAEs. $^{30}$ As discussed above we also include the number of existing R\&D establishments of the relevant type in 2000 to capture any unobserved heterogeneity in the attractiveness of the area for $R \& D$ activity in the relevant product group during the period 
up until 2000. This variable enters positively in all cases but one, and is significant for the chemicals, machinery and TV and radio equipment industries. We also include all our other university-based variables in changes, while the controls for manufacturing employment, diversification, industry specialisation and the skills of the workforce are included in levels to control for any remaining scale and other constant area effects.

As expected given the smaller amount of variation in the changes, the number of significant results is smaller than in the levels specification. This suggests either that some of the levels results were driven by correlated unobserved heterogeneity across areas, or that there has not been sufficient variation over this period in the RAE classifications of relevant departments to identify the effect of changes on R\&D location decisions.

However, our main results for the pharmaceuticals and chemicals sectors remain even in the entrants specification, with a large and highly significant positive effect on the number of entrants in pharmaceuticals of the change in the number of chemistry departments rated 5 or $5 *$, and a positive effect in chemicals of the change in the number of highly rated materials science departments. These results provide even stronger evidence that the location of R\&D-doing establishments in these sectors is affected by the presence of relevant high quality research departments. The effects are large, for example the 8 postcode areas that saw an increase of one in the number of highly rated chemistry departments had an expected number of entrants in pharmaceuticals over 2001-2003 that was almost ten times higher, even after controlling for the number of existing establishments in 2000 and a range of other area controls.

These findings are also robust to the inclusion of our measure of the number of science parks in each area. For example in pharmaceuticals the estimated coefficient on highly rated chemistry departments halves to 4.366 , but remains significant at the $5 \%$ level (z- 
statistic, 2.16). The coefficient (z-statistic) on the number of science parks is positive and significant at $0.282(3.35)$.

We also find a number of other significant effects for changes in the number of relevant departments rated 4 or below, with a significant positive effect of the number of mechanical engineering departments in the machinery industry (but a negative effect in the TV and radio equipment industry), and a positive effect of the number of electrical engineering departments in the TV, radio and communications equipment industry.

[Table 5 here]

\section{Conclusions}

This paper provides the first comprehensive evidence on the extent to which businesssector R\&D activity is located in the vicinity of university research departments in Great Britain. Even after controlling for various sources of observed and unobserved heterogeneity across postcode areas we find robust evidence for the co-location of business R\&D with relevant university research departments. For high quality research departments rated 5 or $5 *$ by the RAE we find consistent evidence of co-location only in the pharmaceuticals and chemicals industries, but we also find positive effects for research departments rated 4 or below in other industries such as machinery and communications equipment. Our strongest results in pharmaceuticals do not appear to be driven solely by the supply of trained students or science professionals, though they do seem to be related to the location of science parks. Some of our results are stronger for the location of foreignowned establishments, consistent with international technology sourcing by multinationals.

As discussed above, the importance of proximity to relevant university research may be driven by a number of underlying economic mechanisms. These range from pure knowledge spillovers mediated through informal networks and face-to-face interactions, to 
formal collaboration agreements, consultancy or university spin-outs. The importance of each of these mechanisms is likely to vary across subject areas and industries, and the implications for policy may be different in each case. Our results in pharmaceuticals and chemicals appear to confirm the importance of world-class centres of research for attracting increasingly footloose $R \& D$ investment. However, the fact that we also find some instances of co-location with lower rated university research departments raises the possibility that firms may benefit both from proximity to frontier basic university research and from more applied public sector research activity. The latter may be measured as low quality research for the purposes of the RAE and funding allocations, but our results suggest that it may play a role in some areas of technology transfer and even in attracting foreign-owned R\&D investment. However, without further supporting evidence on the underlying economic mechanisms at work, it is difficult to make specific policy recommendations based on these results. 


\section{Footnotes}

${ }^{1}$ See Table A.1 in the Appendix for a list of relevant departments. We discuss below how we define which departments are relevant for a specific product group.

${ }^{2}$ See, for example, Cohen et al. (2002) and Abramovsky et al. (2004).

${ }^{3}$ See, for example, Audretsch and Feldman (1996), Audretsch and Feldman (1999), Cohen et al. (2002) Rosenbloom (2004), Andersson and Karlsson, (2005) and Woodward et al. (2006). Also, see Feldman (1999) for a review of this literature.

${ }^{4}$ On the other side of the system, grants for specific projects and programmes are provided by the Research Councils, charities, the European Union and government departments. ${ }^{5}$ See HEFCE (2005).

${ }^{6}$ Lambert Review of Business-University Collaboration: Final Report, (2003).

${ }^{7}$ Establishments can in practice report on R\&D carried out in plants at more than one location, however in 2000 95\% of establishments reported on a single plant. The ONS constructs the data on the population of R\&D-doers using information from other official sources. We use the data over the period 2000 to 2003 as although the data are available over the latter part of the 1990s, there are some significant jumps in the size of the registered population which make the earlier data less reliable for our purposes. ${ }^{8}$ Product groups use the same breakdown as industry groups, see Table A.1 in the Appendix.

${ }^{9}$ This more detailed information is imputed for non-sampled and non-respondent establishments, see National Statistics (2005) for further details, but we do not use this imputed information.

${ }^{10}$ In the robustness section we test that our main results are robust to dropping London from the sample. 
${ }^{11}$ We identify greenfield entrants as new identifier codes appearing in the years 2001 to 2003, which were not present in the population in 2000 .

12 The RAE results are publicly available at http://www.hero.ac.uk/rae/Pubs/index.htm. Though it is not mandatory, the incentives for participation are high as public research funding depends on this assessment.

${ }^{13}$ The Carnegie Mellon Survey on Industrial R\&D is a survey of R\&D managers of R\&D units located in the U.S. conducting R\&D in manufacturing industries. The survey asks firms’ R\&D managers to evaluate, by field, the importance to their $R \& D$ of the contribution of public research conducted over the prior 10 years, using a four-point Likert scale. See Cohen et al. (2002) for a full description of the survey.

${ }^{14}$ We exclude physics from the relevant research fields for the TV, radio and communications equipment product group regression. It is never statistically significant when included and does not affect the results. Physics is not classed as relevant for any of the other product groups we examine.

${ }^{15}$ Equal to (1-H)x100, where $\mathrm{H}=\Sigma s_{i}^{2}$ and $s_{i}$ is the share of employment in 4-digit industry $i$ in total manufacturing employment in the postcode area. The index is increasing in the extent of diversification. See, for example, Rosenthal and Strange (2003). The most diversified areas include a number of large urban areas including Manchester, Birmingham and Sheffield, and the least diversified areas include a number of postcode areas in Scotland, plus the areas around Carlisle and Lancaster covering National Parks.

${ }^{16}$ See, for example, Audretsch and Feldman (1996).

${ }^{17}$ See, for example, Bartel and Lichtenberg (1987).

${ }^{18}$ NOMIS, official labour market statistics for local and national areas, Labour Force Survey. 
${ }^{19}$ The number of establishments performing $R \& D$ in aerospace is small relative to the other product groups, and they are more concentrated geographically. This makes it hard to identify the relevant effects and for this reason we exclude aerospace from the analysis.

${ }^{20}$ In the robustness section we test that our main results are robust to dropping London from the sample.

${ }^{21}$ See Harhoff (1999) for a discussion of these issues in the context of a study of firm formation in Germany.

${ }^{22}$ We use the negative binomial regression instead of the Poisson regression to account for overdispersion. In a Poisson distribution the mean and variance are equal. When the variance is greater than the mean the distribution is said to display overdispersion and Poisson estimation is inappropriate, yielding inefficient estimates. The negative binomial regression corrects for this.

${ }^{23}$ Because of the timing of the RAE this measures the change in research quality over the period 1995 (the end of the 1996 RAE assessment period) to 2000 (the end of the 2001 RAE assessment period).

${ }^{24}$ These controls vary very little over time, and we include them in levels to capture scale effects and agglomeration effects that may not be captured by the number of pre-existing establishments in 2000.

${ }^{25}$ Interestingly this result is in line with the findings of the CMS survey of R\&D managers, with the importance placed on academic research in chemistry by $R \& D$ managers in the drugs industry being one of the strongest findings in the survey. See Table A.2. in the Appendix.

${ }^{26}$ See Griffith, Harrison and Van Reenen (2006) for a discussion of technology sourcing by UK firms. 
${ }^{27}$ Note that this variable is highly endogenous, hence this finding should not be interpreted as causal.

${ }^{28}$ The correlation between the number of science parks and the presence of 5 and $5^{*}$ chemistry departments is 0.51 , with 15 out of the 18 postcode areas with 5 or $5^{*}$ rated chemistry departments containing science parks.

${ }^{29}$ We look only at R\&D services labs performing research in natural sciences and engineering, as opposed to social sciences and humanities.

${ }^{30}$ We do not present separate results for foreign entrants due to the low number of foreign entrants over the period in most of the sectors, making it hard to identify the relevant effects. 


\section{References}

Abramovsky L., Harrison, R. and Simpson, H. (2004). 'Increasing innovative activity in the UK? Where now for government support for innovation and technology transfer', IFS Briefing Note BN53.

Andersson, M. and Karlsson, C. (2005). 'The location of industry R\&D and the location of university R\&D - how are they related?’, CESIS Paper No. 38.

Audretsch, D.B. and Feldman, M.P. (1996). 'R\&D spillovers and the geography of innovation and production', American Economic Review, vol. 86(3), pp.630-640.

Audretsch, D.B. and Feldman, M.P. (1999). 'Innovation in cities: science-based diversity, specialization and localized competition', European Economic Review, vol. 43, pp. 409-429.

Bartel, A.P. and Lichtenberg, F.R. (1987). 'The comparative advantage of educated workers in implementing new technology: some empirical evidence”, Review of Economics and Statistics, vol. LXIX, No. 1, pp. 1-11.

Branstetter, L. and Ogura Y. (2005). 'Is academic science driving a surge in industrial innovation? Evidence from patent citations’, NBER Working Paper No. 11561

Cohen, W., Nelson R. and Walsh, J. (2002). 'Links and impacts: the influence of public research on industrial R\&D’, Management Science, vol. 48(1), pp. 1-23.

Department of Trade and Industry, (2003). Innovation Report - Competing in the Global Economy: The Innovation Challenge, www.dti.gov.uk/innovationreport/

Feldman, M. (1994). The Geography of Innovation, Boston; Kluwer Academic Publishers.

Feldman, M. (1999). 'The new economics of innovation, spillovers and sgglomeration: a review of empirical studies', Economics of Innovation and New Technology, vol. 8, pp. 5-25. 
Griffith, R., Harrison, R. and Van Reenen, J. (2006). 'How special is the special relationship? Using the impact of US R\&D spillovers on UK firms as a test of technology sourcing', American Economic Review, vol. 96(5)

Griffith, R., Redding, S. and Simpson, H. (2004). 'Foreign ownership and productivity: new evidence from the service sector and the R\&D lab’, Oxford Review of Economic Policy, vol. 20(3), 533-564.

Harhoff, D. (1999). 'Firm formation and regional spillovers - evidence from Germany”, Economics of Innovation and New Technology, vol. 8, pp.27-55.

HEFCE (2005). Funding Higher Education in England, http://www.hefce.ac.uk/Pubs/hefce/2005/05_34/05_34.pdf

Jaffe, A. (1989). 'Real effects of academic research”, American Economic Review, vol. 79(5), pp.957-970.

Lambert Review of Business-University Collaboration: Final Report, December 2003, HMSO, www.hm-treasury.gov.uk/media//EA556/lambert_review_final_450.pdf National Statistics (2005). Research and Development in UK Businesses, 2003. Business Monitor MA14, http://www.statistics.gov.uk/downloads/theme_commerce/MA14_2003.pdf

Rosenbloom, J.L. (2004). 'The geography of innovation commercialization in the United States during the 1990s’. The University of Kansas Working Paper Series in Theoretical and Applied Economics, WP Number 200502.

Rosenthal, S.E. and Strange W. C. (2003). ‘Geography, industrial organization, and agglomeration', The Review of Economics and Statistics, vol. 85(2), pp. 377-393.

Woodward, D., Figueiredo, O. and Guimarães P. (2006). 'Beyond the silicon valley: university R\&D and high-technology location', Journal of Urban Economics, vol. 60, pp. 15-32. 
Appendix

[Table A.1 here]

[Table A.2 here]

[Table A.3 here] 
Fig. 1. Distribution of R\&D establishments across postcode areas, 2003

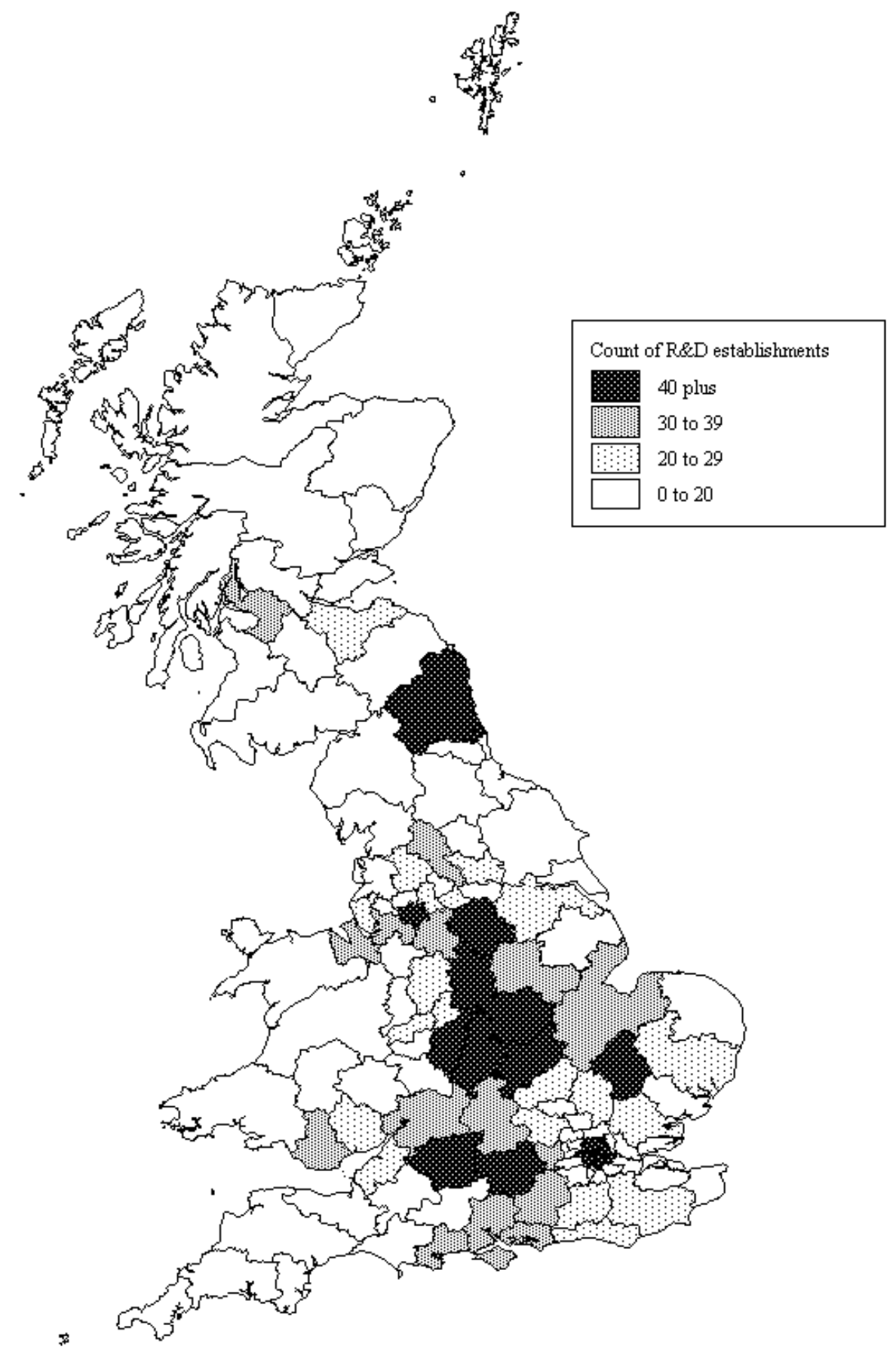

Note: Product groups included are pharmaceuticals, chemicals, machinery, electrical machinery, TV and radio equipment and motor vehicles.

Source: Authors' calculations using BERD (Source: ONS). 
Fig. 2. Distribution of 5 and $5 *$ relevant departments across postcode areas

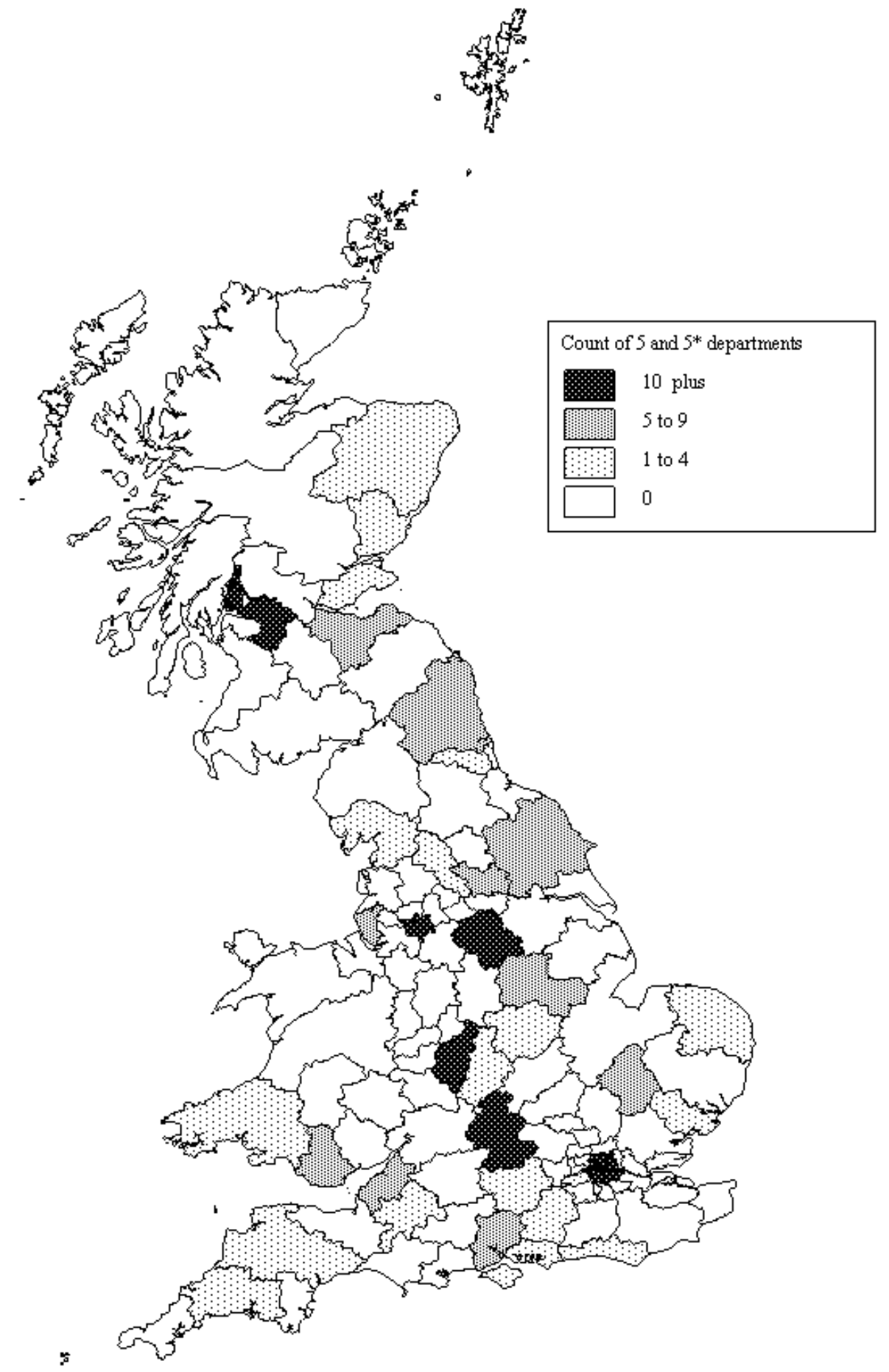

Note: Relevant research departments included shown in Table A.1. in the Appendix. Source: RAE 2001, authors' calculations. 
Table 1. Total intramural R\&D in 2003, by product group, Great Britain.

\begin{tabular}{|c|c|c|c|c|}
\hline \multirow[t]{2}{*}{ Product group } & \multicolumn{2}{|c|}{ Expenditure } & \multicolumn{2}{|c|}{ Establishments } \\
\hline & $£ b n$ & $\%$ & Number & $\%$ \\
\hline Pharmaceuticals & 3.24 & $24 \%$ & 158 & $2 \%$ \\
\hline Aerospace & 1.65 & $12 \%$ & 72 & $1 \%$ \\
\hline Motor vehicles & 1.17 & $9 \%$ & 236 & $2 \%$ \\
\hline Machinery & 0.97 & $7 \%$ & 782 & $7 \%$ \\
\hline TV and radio equipment & 0.93 & $7 \%$ & 250 & $2 \%$ \\
\hline Chemicals & 0.54 & $4 \%$ & 382 & $4 \%$ \\
\hline Electrical machinery & 0.44 & $3 \%$ & 442 & $4 \%$ \\
\hline R\&D services (natural science and engineering) & 0.33 & $2 \%$ & 1,584 & $15 \%$ \\
\hline Other & 4.31 & $32 \%$ & 6,586 & $63 \%$ \\
\hline Total & 13.57 & $100 \%$ & 10,492 & $100 \%$ \\
\hline
\end{tabular}

Source: Authors' calculations using BERD (Source ONS) data.

Table 2. Descriptive statistics: main university research and control variables

\begin{tabular}{|c|c|c|c|c|}
\hline Variable & Mean & $\begin{array}{l}\text { Standard } \\
\text { Deviation }\end{array}$ & $\begin{array}{l}\text { Number of } \\
\text { postcode } \\
\text { areas with } \\
\text { zero }\end{array}$ & $\begin{array}{c}\text { Maximum } \\
\text { in postcode } \\
\text { area }\end{array}$ \\
\hline Dummy: Presence of university & 0.64 & 0.48 & 40 & -- \\
\hline Number of universities & 1.52 & 4.07 & 40 & 42 \\
\hline Average university quality & 2.42 & 1.93 & 40 & 5.58 \\
\hline \multicolumn{5}{|l|}{ Rated 4 and below } \\
\hline Biology & 0.26 & 0.57 & 86 & 4 \\
\hline Chemistry & 0.23 & 0.55 & 92 & 3 \\
\hline Medicine & 1.23 & 3.07 & 66 & 28 \\
\hline Materials science & 0.15 & 0.43 & 97 & 2 \\
\hline Mechanical engineering & 0.22 & 0.49 & 91 & 2 \\
\hline Electrical engineering & 0.21 & 0.54 & 92 & 4 \\
\hline Computer science & 0.48 & 1.17 & 74 & 11 \\
\hline \multicolumn{5}{|l|}{ Rated 5 and $5 *$} \\
\hline Biology & 0.28 & 0.63 & 85 & 5 \\
\hline Chemistry & 0.17 & 0.40 & 93 & 2 \\
\hline Medicine & 0.85 & 2.74 & 86 & 25 \\
\hline Materials science & 0.09 & 0.37 & 104 & 2 \\
\hline Mechanical engineering & 0.16 & 0.53 & 98 & 4 \\
\hline Electrical engineering & 0.17 & 0.46 & 95 & 3 \\
\hline Computer science & 0.22 & 0.43 & 88 & 2 \\
\hline \multicolumn{5}{|l|}{ Control variables } \\
\hline Log (total manufacturing employment) & 10.17 & 0.79 & -- & 12.00 \\
\hline Diversification Index & 96.00 & 2.64 & -- & 98.57 \\
\hline Industry \% manufacturing employment & 4.56 & 5.03 & -- & 36.20 \\
\hline$\%$ population with L4 or above skills & 25.04 & 4.40 & -- & 41.14 \\
\hline Log (number research students in $5,5^{*}$ departments) & 2.51 & 3.04 & -- & 8.99 \\
\hline Log (number research students in 1-4 departments) & 3.20 & 2.67 & -- & 7.96 \\
\hline $\begin{array}{l}\% \text { working population science and technology } \\
\text { professionals \& associate professionals }\end{array}$ & 2.57 & 0.47 & -- & 4.08 \\
\hline Science park dummy & 0.41 & 0.49 & 65 & 1 \\
\hline Number science parks & 0.70 & 1.23 & 65 & 9 \\
\hline
\end{tabular}

Source: Authors’ calculations using ARD-ABI data (Source: ONS), RAE, NOMIS, UKSPA data. 
Table 3. Location of establishments conducting intramural R\&D, average 2000-2003.

\begin{tabular}{|c|c|c|c|c|c|c|c|c|}
\hline \multirow[t]{3}{*}{$\begin{array}{l}\text { Dependant variable: Number of } \\
\text { establishments conducting intramural } \\
\text { R\&D }\end{array}$} & \multicolumn{8}{|c|}{ Product group and ownership } \\
\hline & \multicolumn{2}{|c|}{ Pharmaceuticals } & \multicolumn{2}{|c|}{ Chemicals } & \multicolumn{2}{|c|}{ Machinery } & \multicolumn{2}{|c|}{ Electrical machinery } \\
\hline & All & Foreign & All & Foreign & All & Foreign & All & Foreign \\
\hline Dummy: Presence of university & $\begin{array}{l}-0.423 \\
(0.34)\end{array}$ & $\begin{array}{l}0.213 \\
(0.10)\end{array}$ & $\begin{array}{l}-0.384 \\
(0.58)\end{array}$ & $\begin{array}{l}-0.391 \\
(0.43)\end{array}$ & $\begin{array}{l}-0.523 \\
(1.51)\end{array}$ & $\begin{array}{l}-0.507 \\
(0.70)\end{array}$ & $\begin{array}{l}2.112 \\
(1.31)\end{array}$ & $\begin{array}{l}1.383 \\
(0.87)\end{array}$ \\
\hline Number of universities & $\begin{array}{l}-0.023 \\
(0.38)\end{array}$ & $\begin{array}{l}-0.038 \\
(0.45)\end{array}$ & $\begin{array}{l}-0.010 \\
(0.67)\end{array}$ & $\begin{array}{l}-0.015 \\
(0.79)\end{array}$ & $\begin{array}{l}-0.012 \\
(1.39)\end{array}$ & $\begin{array}{c}-0.055 \\
(2.54)^{*}\end{array}$ & $\begin{array}{c}-0.033 \\
(2.42)^{*}\end{array}$ & $\begin{array}{c}-0.124 \\
(4.94)^{* *}\end{array}$ \\
\hline Average university quality & $\begin{array}{l}0.349 \\
(0.75)\end{array}$ & $\begin{array}{l}-0.014 \\
(0.04)\end{array}$ & $\begin{array}{l}0.120 \\
(0.42)\end{array}$ & $\begin{array}{l}0.086 \\
(0.23)\end{array}$ & $\begin{array}{l}0.150 \\
(0.89)\end{array}$ & $\begin{array}{l}0.357 \\
(1.17)\end{array}$ & $\begin{array}{c}-0.338 \\
(1.57)\end{array}$ & $\begin{array}{c}-0.338 \\
(1.33)\end{array}$ \\
\hline \multicolumn{9}{|l|}{ Number of departments rated 1 to 4 : } \\
\hline Biology & $\begin{array}{l}0.136 \\
(0.54)\end{array}$ & $\begin{array}{r}-0.339 \\
(1.63)\end{array}$ & & & & & & \\
\hline Chemistry & $\begin{array}{l}0.422 \\
(1.97)^{*}\end{array}$ & $\begin{array}{c}0.813 \\
(2.23)^{* *}\end{array}$ & $\begin{array}{l}-0.071 \\
(0.50)\end{array}$ & $\begin{array}{l}-0.038 \\
(0.15)\end{array}$ & & & & \\
\hline Medical & $\begin{array}{l}0.073 \\
(0.93)\end{array}$ & $\begin{array}{l}0.044 \\
(0.40)\end{array}$ & & & & & & \\
\hline Materials science & & & $\begin{array}{l}0.056 \\
(0.38)\end{array}$ & $\begin{array}{l}-0.095 \\
(0.44)\end{array}$ & $\begin{array}{l}-0.027 \\
(0.39)\end{array}$ & $\begin{array}{c}0.516 \\
(3.22)^{* *}\end{array}$ & & \\
\hline Computer science & & & & & & & & \\
\hline Electrical engineering & & & & & & & $\begin{array}{l}0.086 \\
(0.74)\end{array}$ & $\begin{array}{c}0.688 \\
(2.61)^{* *}\end{array}$ \\
\hline Mechanical engineering & & & & & $\begin{array}{c}-0.059 \\
(0.63)\end{array}$ & $\begin{array}{l}0.140 \\
(0.86)\end{array}$ & & \\
\hline \multicolumn{9}{|l|}{ Number of departments rated 5 and $5^{*}$} \\
\hline Biology & $\begin{array}{c}-0.748 \\
(3.98)^{* *}\end{array}$ & $\begin{array}{c}-0.833 \\
(3.10)^{* *}\end{array}$ & & & & & & \\
\hline Chemistry & $\begin{array}{c}1.828 \\
(2.81)^{*}\end{array}$ & $\begin{array}{c}2.672 \\
(2.70)^{* *}\end{array}$ & $\begin{array}{l}-0.089 \\
(0.28)\end{array}$ & $\begin{array}{l}-0.219 \\
(0.56)\end{array}$ & & & & \\
\hline Medical & $\begin{array}{l}0.077 \\
(1.00)\end{array}$ & $\begin{array}{c}0.220 \\
(2.17)^{*}\end{array}$ & & & & & & \\
\hline Materials science & & & $\begin{array}{c}0.475 \\
(2.74)^{* *}\end{array}$ & $\begin{array}{l}0.323 \\
(1.53)\end{array}$ & $\begin{array}{l}0.062 \\
(0.90)\end{array}$ & $\begin{array}{l}-0.135 \\
(0.82)\end{array}$ & & \\
\hline \multicolumn{9}{|l|}{ Computer science } \\
\hline Electrical engineering & & & & & & & $\begin{array}{l}0.011 \\
(0.07)\end{array}$ & $\begin{array}{l}0.104 \\
(0.34)\end{array}$ \\
\hline Mechanical engineering & & & & & $\begin{array}{l}-0.073 \\
(0.86)\end{array}$ & $\begin{array}{l}-0.037 \\
(0.20)\end{array}$ & & \\
\hline Log manufacturing employment & $\begin{array}{c}0.950 \\
(4.04)^{* *}\end{array}$ & $\begin{array}{c}0.970 \\
(2.91)^{* *}\end{array}$ & $\begin{array}{c}1.517 \\
(6.48)^{* *}\end{array}$ & $\begin{array}{c}1.660 \\
(5.06)^{* *}\end{array}$ & $\begin{array}{c}1.643 \\
(13.13)^{* *}\end{array}$ & $\begin{array}{c}1.608 \\
(6.43)^{* *}\end{array}$ & $\begin{array}{c}1.111 \\
(6.34)^{* *}\end{array}$ & $\begin{array}{c}1.707 \\
(4.37)^{* *}\end{array}$ \\
\hline Diversification index & $\begin{array}{l}0.112 \\
(1.33)\end{array}$ & $\begin{array}{l}0.028 \\
(0.23)\end{array}$ & $\begin{array}{l}0.023 \\
(1.08)\end{array}$ & $\begin{array}{r}-0.037 \\
(0.96)\end{array}$ & $\begin{array}{l}0.037 \\
(1.73)\end{array}$ & $\begin{array}{r}-0.043 \\
(1.22)\end{array}$ & $\begin{array}{l}0.045 \\
(1.19)\end{array}$ & $\begin{array}{l}-0.056 \\
(1.10)\end{array}$ \\
\hline $\begin{array}{l}\text { Industry \% manufacturing } \\
\text { employment }\end{array}$ & $\begin{array}{c}0.073 \\
(2.98)^{* *}\end{array}$ & $\begin{array}{l}0.060 \\
(1.90)\end{array}$ & $\begin{array}{c}0.065 \\
(6.58)^{* *}\end{array}$ & $\begin{array}{c}0.068 \\
(6.08)^{* *}\end{array}$ & $\begin{array}{c}0.050 \\
(6.26)^{* *}\end{array}$ & $\begin{array}{c}0.077 \\
(5.18)^{* *}\end{array}$ & $\begin{array}{c}0.087 \\
(4.66)^{* *}\end{array}$ & $\begin{array}{c}0.134 \\
(4.66)^{* *}\end{array}$ \\
\hline$\%$ population with L4 or above skills & $\begin{array}{c}0.159 \\
(5.88)^{* *}\end{array}$ & $\begin{array}{c}0.109 \\
(2.97)^{* *}\end{array}$ & $\begin{array}{l}0.022 \\
(1.28)\end{array}$ & $\begin{array}{c}0.046 \\
(2.28)^{*}\end{array}$ & $\begin{array}{l}0.011 \\
(1.15)\end{array}$ & $\begin{array}{c}0.034 \\
(2.04)^{*}\end{array}$ & $\begin{array}{c}0.059 \\
(4.20)^{* *}\end{array}$ & $\begin{array}{c}0.082 \\
(3.10)^{* *}\end{array}$ \\
\hline $\begin{array}{l}\text { Log total no. research students in 5,5* } \\
\text { departments } \\
\text { Log total no. research students in 1-4 } \\
\text { departments }\end{array}$ & $\begin{array}{l}0.022 \\
(0.19) \\
0.841 \\
(0.96)\end{array}$ & $\begin{array}{l}0.072 \\
(0.45) \\
-0.048 \\
(0.17)\end{array}$ & $\begin{array}{l}-0.072 \\
(0.99) \\
0.050 \\
(0.61)\end{array}$ & $\begin{array}{l}-0.018 \\
(0.19) \\
0.040 \\
(0.35)\end{array}$ & $\begin{array}{l}-0.037 \\
(0.88) \\
0.089 \\
(1.37)\end{array}$ & $\begin{array}{l}-0.011 \\
(0.13) \\
-0.084 \\
(0.76)\end{array}$ & $\begin{array}{l}0.141 \\
(1.31) \\
-0.013 \\
(0.14)\end{array}$ & $\begin{array}{l}0.134 \\
(1.11) \\
-0.006 \\
(0.04)\end{array}$ \\
\hline Pseudo R-squared & 0.22 & 0.19 & 0.20 & 0.18 & 0.26 & 0.21 & 0.18 & 0.18 \\
\hline $\begin{array}{l}\text { Number of observations with } \\
\text { dependent variable equal to zero }\end{array}$ & 40 & 70 & 9 & 43 & 4 & 29 & 8 & 42 \\
\hline $\begin{array}{l}\text { Dependent variable mean } \\
\text { (standard error) } \\
\text { [Maximum in a postcode area] }\end{array}$ & $\begin{array}{c}1.49 \\
(2.11) \\
{[12]}\end{array}$ & $\begin{array}{c}0.56 \\
(0.87) \\
{[4]}\end{array}$ & $\begin{array}{c}3.65 \\
(3.93) \\
{[21]}\end{array}$ & $\begin{array}{c}0.98 \\
(1.12) \\
{[5]}\end{array}$ & $\begin{array}{c}6.83 \\
(5.89) \\
{[40]}\end{array}$ & $\begin{array}{c}1.38 \\
(1.60) \\
{[11]}\end{array}$ & $\begin{array}{c}3.63 \\
(3.21) \\
{[13]}\end{array}$ & $\begin{array}{c}1.06 \\
(1.38) \\
{[9]}\end{array}$ \\
\hline Observations & 111 & 111 & 111 & 111 & 111 & 111 & 111 & 111 \\
\hline
\end{tabular}

Values shown are incident rate ratios minus one. z-statistics in parentheses. * significant at 5\% level, ** significant at $1 \%$ level.

Source: Authors’ calculations using BERD, ARD-ABI (Source: ONS), RAE and NOMIS data. 


\section{...Table 3 continued:}

Location of establishments conducting intramural R\&D, average 2000-2003.

\begin{tabular}{|c|c|c|c|c|}
\hline \multirow{3}{*}{$\begin{array}{l}\text { Dependant variable: Number of } \\
\text { establishments conducting intramural } \\
\text { R\&D }\end{array}$} & \multicolumn{4}{|c|}{ Product group and ownership } \\
\hline & \multicolumn{2}{|c|}{ TV and radio equipment } & \multicolumn{2}{|c|}{ Motor vehicles } \\
\hline & All & Foreign & All & Foreign \\
\hline Dummy: Presence of university & $\begin{array}{l}-0.221 \\
(0.21)\end{array}$ & $\begin{array}{l}0.846 \\
(0.33)\end{array}$ & $\begin{array}{l}-0.080 \\
(0.08)\end{array}$ & $\begin{array}{l}-0.344 \\
(0.22)\end{array}$ \\
\hline Number of universities & $\begin{array}{l}0.081 \\
(1.73)\end{array}$ & $\begin{array}{l}0.001 \\
(0.01)\end{array}$ & $\begin{array}{l}0.024 \\
(1.24)\end{array}$ & $\begin{array}{l}0.040 \\
(1.52)\end{array}$ \\
\hline Average university quality & $\begin{array}{l}-0.206 \\
(0.58)\end{array}$ & $\begin{array}{l}-0.370 \\
(0.98)\end{array}$ & $\begin{array}{l}-0.157 \\
(0.53)\end{array}$ & $\begin{array}{l}0.042 \\
(0.09)\end{array}$ \\
\hline \multicolumn{5}{|l|}{ Number of departments rated 1 to 4 : } \\
\hline \multicolumn{5}{|l|}{ Biology } \\
\hline \multicolumn{5}{|l|}{ Chemistry } \\
\hline \multicolumn{5}{|l|}{ Medical } \\
\hline Materials science & $\begin{array}{l}0.067 \\
(0.28)\end{array}$ & $\begin{array}{l}-0.152 \\
(0.55)\end{array}$ & $\begin{array}{l}-0.201 \\
(1.65)\end{array}$ & $\begin{array}{l}0.036 \\
(0.18)\end{array}$ \\
\hline Computer science & $\begin{array}{l}-0.322 \\
(2.55)^{*}\end{array}$ & $\begin{array}{l}-0.141 \\
(0.53)\end{array}$ & & \\
\hline Electrical engineering & $\begin{array}{l}-0.165 \\
(0.79)\end{array}$ & $\begin{array}{l}-0.057 \\
(0.14)\end{array}$ & & \\
\hline Mechanical engineering & $\begin{array}{l}-0.137 \\
(0.63)\end{array}$ & $\begin{array}{l}-0.358 \\
(1.19)\end{array}$ & $\begin{array}{l}-0.220 \\
(1.56)\end{array}$ & $\begin{array}{r}-0.028 \\
(0.11)\end{array}$ \\
\hline \multicolumn{5}{|l|}{ Number of departments rated 5 and $5 *$} \\
\hline \multicolumn{5}{|l|}{ Biology } \\
\hline \multicolumn{5}{|l|}{ Chemistry } \\
\hline \multicolumn{5}{|l|}{ Medical } \\
\hline Materials science & $\begin{array}{l}-0.141 \\
(0.58)\end{array}$ & $\begin{array}{l}-0.214 \\
(0.47)\end{array}$ & $\begin{array}{r}-0.032 \\
(0.17)\end{array}$ & $\begin{array}{c}-0.093 \\
(0.49)\end{array}$ \\
\hline Computer science & $\begin{array}{l}-0.330 \\
(1.71)\end{array}$ & $\begin{array}{l}0.346 \\
(0.72)\end{array}$ & & \\
\hline Electrical engineering & $\begin{array}{l}-0.221 \\
(0.96)\end{array}$ & $\begin{array}{l}0.641 \\
(1.24)\end{array}$ & & \\
\hline Mechanical engineering & $\begin{array}{l}0.261 \\
(1.02)\end{array}$ & $\begin{array}{l}-0.358 \\
(0.82)\end{array}$ & $\begin{array}{l}-0.233 \\
(1.93)\end{array}$ & $\begin{array}{l}-0.338 \\
(1.48)\end{array}$ \\
\hline Log manufacturing employment & $\begin{array}{c}1.036 \\
(3.67)^{* *}\end{array}$ & $\begin{array}{c}0.861 \\
(2.04)^{*}\end{array}$ & $\begin{array}{c}1.775 \\
(6.42)^{* *}\end{array}$ & $\begin{array}{c}1.364 \\
(3.94)^{* *}\end{array}$ \\
\hline Diversification index & $\begin{array}{r}0.040 \\
(0.82)\end{array}$ & $\begin{array}{l}0.052 \\
(0.90)\end{array}$ & $\begin{array}{c}0.134 \\
(2.03)^{*}\end{array}$ & $\begin{array}{c}0.222 \\
(2.43)^{*}\end{array}$ \\
\hline Industry \% manufacturing employment & $\begin{array}{c}0.083 \\
(4.00)^{* *}\end{array}$ & $\begin{array}{c}0.088 \\
(3.94)^{* *}\end{array}$ & $\begin{array}{c}0.064 \\
(5.28)^{* *}\end{array}$ & $\begin{array}{c}0.076 \\
(4.64)^{* *}\end{array}$ \\
\hline $\begin{array}{l}\text { Proportion of population with L4 or } \\
\text { above skills }\end{array}$ & $\begin{array}{c}0.087 \\
(4.35)^{* *}\end{array}$ & $\begin{array}{c}0.157 \\
(4.25)^{* *}\end{array}$ & $\begin{array}{l}0.033 \\
(1.85)\end{array}$ & $\begin{array}{r}-0.014 \\
(0.49)\end{array}$ \\
\hline $\begin{array}{l}\text { Log total no. research students in } 5,5^{*} \\
\text { departments }\end{array}$ & $\begin{array}{l}0.095 \\
(0.86)\end{array}$ & $\begin{array}{c}-0.026 \\
(0.17)\end{array}$ & $\begin{array}{l}0.005 \\
(0.06)\end{array}$ & $\begin{array}{l}0.017 \\
(0.12)\end{array}$ \\
\hline $\begin{array}{l}\text { Log total no. research students in 1-4 } \\
\text { departments }\end{array}$ & $\begin{array}{c}0.243 \\
(2.19)^{*}\end{array}$ & $\begin{array}{l}0.195 \\
(0.85)\end{array}$ & $\begin{array}{l}0.119 \\
(0.91)\end{array}$ & $\begin{array}{r}-0.005 \\
(0.02)\end{array}$ \\
\hline Pseudo R-squared & 0.17 & 0.17 & 0.25 & 0.22 \\
\hline $\begin{array}{l}\text { Number of observations with dependent } \\
\text { variable equal to zero }\end{array}$ & 17 & 61 & 23 & 52 \\
\hline $\begin{array}{l}\text { Dependent variable mean } \\
\text { (standard error) } \\
\text { [Maximum in a postcode area] }\end{array}$ & $\begin{array}{c}2.32 \\
(2.47) \\
{[10]}\end{array}$ & $\begin{array}{c}0.69 \\
(1.04) \\
{[5]}\end{array}$ & $\begin{array}{c}2.03 \\
(2.73) \\
{[21]}\end{array}$ & $\begin{array}{c}0.87 \\
(1.40) \\
{[11]}\end{array}$ \\
\hline Observations & 111 & 111 & 111 & 111 \\
\hline
\end{tabular}

Values shown are incident rate ratios minus one. z-statistics in parentheses. * significant at $5 \%$ level, ** significant at $1 \%$ level. Source: Authors' calculations using BERD, ARD-ABI (Source: ONS), RAE and NOMIS data. 
Table 4. Robustness, pharmaceuticals R\&D

\begin{tabular}{|c|c|c|c|c|c|c|}
\hline $\begin{array}{l}\text { Dependant variable: Number of } \\
\text { establishments conducting intramural R\&D }\end{array}$ & \multicolumn{5}{|c|}{ Pharmaceuticals } & $\begin{array}{c}\mathrm{R} \& \mathrm{D} \\
\text { services } \\
\text { (6) }\end{array}$ \\
\hline Biology & $\begin{array}{l}0.171 \\
(0.63)\end{array}$ & $\begin{array}{l}0.090 \\
(0.38)\end{array}$ & $\begin{array}{l}0.133 \\
(0.63)\end{array}$ & $\begin{array}{l}0.064 \\
(0.27)\end{array}$ & $\begin{array}{c}0.404 \\
(2.23)^{*}\end{array}$ & $\begin{array}{c}-0.088 \\
(0.66)\end{array}$ \\
\hline Chemistry & $\begin{array}{l}0.413 \\
(1.95)\end{array}$ & $\begin{array}{c}0.658 \\
(2.59)^{* *}\end{array}$ & $\begin{array}{c}0.539 \\
(2.38)^{*}\end{array}$ & $\begin{array}{l}0.352 \\
(1.81)\end{array}$ & $\begin{array}{l}0.126 \\
(0.73)\end{array}$ & $\begin{array}{l}0.133 \\
(0.82)\end{array}$ \\
\hline Medical & $\begin{array}{l}0.067 \\
(0.86)\end{array}$ & $\begin{array}{l}0.130 \\
(1.39)\end{array}$ & $\begin{array}{c}0.166 \\
(1.99)^{*}\end{array}$ & $\begin{array}{l}0.022 \\
(0.29)\end{array}$ & $\begin{array}{l}0.059 \\
(0.90)\end{array}$ & $\begin{array}{c}-0.128 \\
(3.33)^{* *}\end{array}$ \\
\hline Chemistry & $\begin{array}{c}1.793 \\
(2.83)^{* *}\end{array}$ & $\begin{array}{c}1.997 \\
(2.80)^{* *}\end{array}$ & $\begin{array}{l}1.531 \\
(2.44)^{*}\end{array}$ & $\begin{array}{c}1.588 \\
(2.59)^{* *}\end{array}$ & $\begin{array}{l}0.173 \\
(0.46)\end{array}$ & $\begin{array}{c}0.544 \\
(2.00)^{*}\end{array}$ \\
\hline Medical & $\begin{array}{l}0.083 \\
(1.10)\end{array}$ & $\begin{array}{l}0.023 \\
(0.32)\end{array}$ & $\begin{array}{l}0.110 \\
(1.55)\end{array}$ & $\begin{array}{l}0.058 \\
(0.79)\end{array}$ & $\begin{array}{l}-0.009 \\
(0.21)\end{array}$ & $\begin{array}{c}0.102 \\
(2.14)^{*}\end{array}$ \\
\hline $\begin{array}{l}\text { \% working pop. science and technology } \\
\text { professionals \& associate professionals }\end{array}$ & & & $\begin{array}{c}1.493 \\
(3.74)^{* *}\end{array}$ & & & \\
\hline Science park dummy & & & & $\begin{array}{l}0.580 \\
(1.89)\end{array}$ & & \\
\hline Number science parks & & & & & $\begin{array}{c}0.294 \\
(6.46)^{* *}\end{array}$ & \\
\hline
\end{tabular}

All specifications include controls: dummy presence of university, number of universities, average university quality, log manufacturing employment, diversification index, pharmaceutical industry \% manufacturing employment, \% population with L4 or above skills, log total no. research students in 5,5* departments, log total no. research students in 1-4 departments.

Region dummies are relative to Southern England, IRR-1 (z-statistic): Midlands -0.518 (2.13)*; Northern England -0.361 (1.75); Wales -0.710 (3.24)**; Scotland -0.392 (1.62).

Values shown are incident rate ratios minus one. z-statistics in parentheses. * significant at 5\% level, ** significant at $1 \%$ level.

Source: Authors’ calculations using BERD, ARD-ARD (Source: ONS), RAE, NOMIS and UKSPA data. 
Table 5. Location of entrants conducting intramural R\&D, 2001-2003.

\begin{tabular}{|c|c|c|c|c|c|c|}
\hline \multirow{2}{*}{$\begin{array}{l}\text { Dependant variable: Number of } \\
\text { entrant establishments conducting } \\
\text { intramural R\&D }\end{array}$} & \multicolumn{6}{|c|}{ Product group } \\
\hline & Pharmaceuticals & Chemicals & Machinery & $\begin{array}{l}\text { Electrical } \\
\text { machinery }\end{array}$ & $\begin{array}{l}\text { TV and radio } \\
\text { equipment }\end{array}$ & $\begin{array}{c}\text { Motor } \\
\text { vehicles }\end{array}$ \\
\hline Number of est. in 2000 & $\begin{array}{l}0.126 \\
(1.16)\end{array}$ & $\begin{array}{c}0.060 \\
(2.56)^{*}\end{array}$ & $\begin{array}{c}0.035 \\
(2.43)^{*}\end{array}$ & $\begin{array}{l}0.068 \\
(1.38)\end{array}$ & $\begin{array}{c}0.107 \\
(2.39)^{*}\end{array}$ & $\begin{array}{c}-0.011 \\
(0.35)\end{array}$ \\
\hline $\begin{array}{l}\text { Change in dummy: Presence of } \\
\text { university }\end{array}$ & $\begin{array}{l}-0.679 \\
(0.71)\end{array}$ & $\begin{array}{l}-0.815 \\
(2.06)^{*}\end{array}$ & $\begin{array}{l}-0.465 \\
(0.81)\end{array}$ & $\begin{array}{l}-0.567 \\
(1.72)\end{array}$ & $\begin{array}{l}-0.970 \\
(2.98)^{* *}\end{array}$ & $\begin{array}{l}-0.842 \\
(1.88)\end{array}$ \\
\hline Change in number of universities & $\begin{array}{l}0.408 \\
(0.70)\end{array}$ & $\begin{array}{l}0.250 \\
(0.92)\end{array}$ & $\begin{array}{l}0.029 \\
(0.18)\end{array}$ & $\begin{array}{c}0.331 \\
(1.97)^{*}\end{array}$ & $\begin{array}{l}0.484 \\
(1.22)\end{array}$ & $\begin{array}{l}0.324 \\
(1.03)\end{array}$ \\
\hline $\begin{array}{l}\text { Change in average university } \\
\text { quality }\end{array}$ & $\begin{array}{l}-0.370 \\
(0.73)\end{array}$ & $\begin{array}{l}0.286 \\
(1.21)\end{array}$ & $\begin{array}{l}0.353 \\
(1.55)\end{array}$ & $\begin{array}{l}-0.004 \\
(0.02)\end{array}$ & $\begin{array}{r}-0.086 \\
(0.30)\end{array}$ & $\begin{array}{l}-0.022 \\
(0.08)\end{array}$ \\
\hline \multicolumn{7}{|c|}{ Change in number of departments rated 1 to 4 : } \\
\hline Biology & $\begin{array}{l}0.441 \\
(0.66)\end{array}$ & & & & & \\
\hline Chemistry & $\begin{array}{l}0.993 \\
(1.56)\end{array}$ & $\begin{array}{l}0.184 \\
(0.59)\end{array}$ & & & & \\
\hline Medical & $\begin{array}{r}-0.004 \\
(0.02)\end{array}$ & & & & & \\
\hline Materials science & & $\begin{array}{l}0.341 \\
(1.65)\end{array}$ & $\begin{array}{l}0.140 \\
(1.16)\end{array}$ & & $\begin{array}{l}0.225 \\
(0.77)\end{array}$ & $\begin{array}{l}0.278 \\
(1.49)\end{array}$ \\
\hline Computer science & & & & & $\begin{array}{l}-0.375 \\
(1.60)\end{array}$ & \\
\hline Electrical engineering & & & & $\begin{array}{l}0.264 \\
(1.18)\end{array}$ & $\begin{array}{c}1.018 \\
(2.09)^{*}\end{array}$ & \\
\hline Mechanical engineering & & & $\begin{array}{c}0.246 \\
(3.58)^{* *}\end{array}$ & & $\begin{array}{l}-0.346 \\
(1.98)^{*}\end{array}$ & $\begin{array}{l}-0.044 \\
(0.27)\end{array}$ \\
\hline \multicolumn{7}{|c|}{ Change in number of departments rated 5 and $5^{*}$} \\
\hline Biology & $\begin{array}{l}1.166 \\
(1.00)\end{array}$ & & & & & \\
\hline Chemistry & $\begin{array}{c}9.504 \\
(2.81)^{* *}\end{array}$ & $\begin{array}{l}-0.287 \\
(0.49)\end{array}$ & & & & \\
\hline Medical & $\begin{array}{l}-0.073 \\
(0.39)\end{array}$ & & & & & \\
\hline Materials science & & $\begin{array}{c}3.239 \\
(2.38)^{*}\end{array}$ & $\begin{array}{l}0.340 \\
(0.96)\end{array}$ & & $\begin{array}{l}-0.578 \\
(1.44)\end{array}$ & $\begin{array}{l}-0.267 \\
(1.09)\end{array}$ \\
\hline Computer science & & & & & $\begin{array}{l}-0.248 \\
(0.55)\end{array}$ & \\
\hline Electrical engineering & & & & $\begin{array}{l}-0.450 \\
(1.90)\end{array}$ & $\begin{array}{l}-0.369 \\
(0.99)\end{array}$ & \\
\hline Mechanical engineering & & & $\begin{array}{r}0.166 \\
(1.13)\end{array}$ & & $\begin{array}{l}-0.115 \\
(0.42)\end{array}$ & $\begin{array}{l}-0.226 \\
(1.00)\end{array}$ \\
\hline Log manufacturing employment & $\begin{array}{l}0.676 \\
(1.13)\end{array}$ & $\begin{array}{c}0.733 \\
(3.36)^{* *}\end{array}$ & $\begin{array}{c}0.747 \\
(3.40)^{* *}\end{array}$ & $\begin{array}{c}2.158 \\
(6.05)^{* *}\end{array}$ & $\begin{array}{c}1.306 \\
(2.66)^{* *}\end{array}$ & $\begin{array}{c}1.392 \\
(3.73)^{* *}\end{array}$ \\
\hline Diversification index & $\begin{array}{l}0.504 \\
(1.41)\end{array}$ & $\begin{array}{l}0.050 \\
(0.90)\end{array}$ & $\begin{array}{l}0.035 \\
(0.77)\end{array}$ & $\begin{array}{l}-0.042 \\
(0.77)\end{array}$ & $\begin{array}{l}0.178 \\
(1.49)\end{array}$ & $\begin{array}{c}0.252 \\
(2.56)^{*}\end{array}$ \\
\hline $\begin{array}{l}\text { Industry \% manufacturing } \\
\text { employment }\end{array}$ & $\begin{array}{l}0.084 \\
(1.79)\end{array}$ & $\begin{array}{c}0.028 \\
(2.02)^{*}\end{array}$ & $\begin{array}{c}0.034 \\
(2.11)^{*}\end{array}$ & $\begin{array}{l}0.077 \\
(1.77)\end{array}$ & $\begin{array}{l}0.076 \\
(1.65)\end{array}$ & $\begin{array}{c}0.071 \\
(3.22)^{* *}\end{array}$ \\
\hline Proportion of population with L4 & 0.029 & -0.012 & 0.028 & 0.001 & 0.093 & -0.013 \\
\hline Change in log total no. research & -0.577 & -0.349 & 0.295 & -0.274 & -0.671 & -0.848 \\
\hline students in $5,5^{*}$ departments & $(0.45)$ & $(0.53)$ & $(0.71)$ & $(0.55)$ & $(1.32)$ & $(3.00)^{* *}$ \\
\hline Change in log total no. research & -0.127 & -0.433 & 0.039 & 0.667 & 0.093 & 0.415 \\
\hline students in 1-4 departments & $(0.24)$ & $(1.23)$ & $(0.13)$ & $(2.92)^{* *}$ & $(0.15)$ & $(1.16)$ \\
\hline Pseudo R-squared & 0.18 & 0.20 & 0.16 & 0.17 & 0.21 & 0.21 \\
\hline $\begin{array}{l}\text { Number of observations with } \\
\text { dependent variable equal to zero }\end{array}$ & 85 & 104 & 44 & 85 & 23 & 81 \\
\hline $\begin{array}{l}\text { Dependent variable mean } \\
\text { (standard error) }\end{array}$ & $\begin{array}{c}0.32 \\
(0.70)\end{array}$ & $\begin{array}{c}0.10 \\
(0.46)\end{array}$ & $\begin{array}{l}1.19 \\
(1.37)\end{array}$ & $\begin{array}{c}0.31 \\
(0.71)\end{array}$ & $\begin{array}{l}2.67 \\
(2.69)\end{array}$ & $\begin{array}{c}0.50 \\
(1.38)\end{array}$ \\
\hline [Maximum in a postcode area] & {$[4]$} & {$[4]$} & {$[7]$} & {$[5]$} & {$[14]$} & {$[12]$} \\
\hline Observations & 111 & 111 & 111 & 111 & 111 & 111 \\
\hline
\end{tabular}

Values shown are incident rate ratios minus one. z-statistics in parentheses. ${ }^{*}$ significant at $5 \%$ level, ${ }^{* *}$ significant at $1 \%$ level.

Source: Authors' calculations using BERD, ARD-ABI (Source: ONS), RAE and NOMIS data. 


\section{Appendix}

Table A.1. Linking R\&D product groups, industries, research fields and departments

\begin{tabular}{|c|c|c|c|c|c|}
\hline $\begin{array}{l}\text { R\&D product } \\
\text { group }\end{array}$ & $\begin{array}{l}\text { Corresponds to products } \\
\text { in BERD }\end{array}$ & $\begin{array}{l}\text { Corresponds to UK SIC92 } \\
\text { codes }\end{array}$ & $\begin{array}{l}\text { Corresponds to US } \\
\text { industry codes in CMS } \\
\text { Cohen et al. } 2002\end{array}$ & $\begin{array}{l}\text { Relevant fields } \\
\text { (CMS, Cohen } \\
\text { et al., 2002) }{ }^{1}\end{array}$ & UK university departments (RAE 2001) \\
\hline Pharmaceuticals & $15(\mathrm{H})$ pharmaceuticals & 24.4 & 2423 & $\begin{array}{l}\text { BIO } \\
\text { CHEM } \\
\text { MED }\end{array}$ & $\begin{array}{l}14 \text { Biology } \\
18 \text { Chemistry } \\
1 \text { to } 5 \text { Clinical medicine, } 6 \text { Anatomy, } 7 \text { Physiology, } \\
8 \text { Pharmacology, } 9 \text { Pharmacy, } 10 \text { to } 11 \text { Other medical }\end{array}$ \\
\hline Chemicals & $14(\mathrm{G})$ chemicals & 24 (excl. 24.4) & 2400241124132429 & $\begin{array}{l}\text { CHEM } \\
\text { MATSCI }\end{array}$ & $\begin{array}{l}18 \text { Chemistry } \\
32 \text { Metallurgy and materials }\end{array}$ \\
\hline $\begin{array}{l}\text { Electrical } \\
\text { Machinery }\end{array}$ & $\begin{array}{l}23(\mathrm{P}) \text { electrical } \\
\text { machinery }\end{array}$ & 31 & 31003110 & $\mathrm{EE}$ & 29 Electrical and electronic engineering \\
\hline $\begin{array}{l}\text { TV and radio } \\
\text { equipment }\end{array}$ & $24(\mathrm{Q}) \mathrm{TV} /$ radio & 32 & 3210321132203230 & $\begin{array}{l}\text { MATSCI }^{2} \\
\text { COMPSCI } \\
\text { EE } \\
\text { MECHE }\end{array}$ & $\begin{array}{l}32 \text { Metallurgy and materials } \\
25 \text { Computer science } \\
29 \text { Electrical and electronic engineering } \\
30 \text { Mechanical, aeronautical and manufacturing engineering }\end{array}$ \\
\hline Motor vehicles & 26 (S) motor vehicles & 34 & 34103430 & $\begin{array}{l}\text { MATSCI } \\
\text { EE } \\
\text { MECHE }\end{array}$ & $\begin{array}{l}32 \text { Metallurgy and materials } \\
29 \text { Electrical and electronic engineering } \\
30 \text { Mechanical, aeronautical and manufacturing engineering }\end{array}$ \\
\hline
\end{tabular}

${ }^{1}$ University sectors that over $50 \%$ respondents say are moderately or very important in this industry.

${ }^{2}$ We exclude PHYSICS from the relevant research fields for this product group to reduce the number of right hand side variables in the regression. It is never statistically significant when included. 
Table A.2. Importance of academic research in different fields of science for industrial $R \& D$ managers in the US

\begin{tabular}{|c|c|c|c|c|c|c|c|c|c|c|c|c|}
\hline \multicolumn{13}{|c|}{ Percentage of respondents indicating research "moderately important" or "very important" } \\
\hline $\begin{array}{l}\text { Industry } \\
\text { (ISIC } \\
\text { code) }\end{array}$ & Description & $\begin{array}{l}\text { Sample } \\
\text { size }\end{array}$ & $\mathrm{BIO}$ & CHEM & PHYS & COMPSC & MATSC & MED & CHEME & $\mathrm{EE}$ & MECHE & MATH \\
\hline 2400 & Chemicals & 75 & 13.3 & 52.0 & 8.0 & 24.0 & 22.7 & 17.3 & 34.7 & 1.3 & 5.3 & 5.3 \\
\hline 2411 & Basic Chemicals & 42 & 14.3 & 47.6 & 7.1 & 23.8 & 23.8 & 16.7 & 40.5 & 2.4 & 4.8 & 2.4 \\
\hline 2413 & Plastic Resins & 30 & 13.3 & 56.7 & 13.3 & 30.0 & 50.0 & 6.7 & 46.7 & 3.3 & 3.3 & 6.7 \\
\hline 2423 & Drugs & 70 & 64.3 & 74.3 & 7.1 & 30.0 & 26.5 & 75.7 & 22.9 & 5.7 & 5.7 & 4.3 \\
\hline 2429 & Miscellaneous Chemicals & 32 & 12.5 & 62.5 & 9.4 & 31.3 & 46.9 & 12.5 & 37.5 & 3.1 & 12.5 & 9.4 \\
\hline 2910 & $\begin{array}{l}\text { General Purpose } \\
\text { Machinery }\end{array}$ & 79 & 1.3 & 13.9 & 10.1 & 29.1 & 53.2 & 5.1 & 21.5 & 26.6 & 59.5 & 10.3 \\
\hline 2920 & $\begin{array}{l}\text { Special Purpose } \\
\text { Machinery }\end{array}$ & 74 & 10.8 & 23.0 & 25.7 & 35.1 & 38.4 & 5.4 & 20.3 & 31.1 & 36.5 & 14.9 \\
\hline 2922 & Machine Tools & 11 & 0.0 & 0.0 & 0.0 & 36.4 & 36.4 & 0.0 & 0.0 & 27.3 & 36.4 & 0.0 \\
\hline 3100 & Electrical Equipment & 23 & 0.0 & 13.0 & 8.7 & 8.7 & 21.7 & 8.7 & 8.7 & 17.4 & 21.7 & 8.7 \\
\hline 3110 & Motor/Generators & 24 & 0.0 & 4.2 & 12.5 & 29.2 & 41.7 & 0.0 & 4.2 & 58.3 & 33.3 & 8.3 \\
\hline 3210 & Electronic Components & 28 & 3.6 & 25.0 & 28.6 & 32.1 & 53.6 & 7.1 & 10.7 & 63.0 & 50.0 & 28.6 \\
\hline 3211 & Semiconductors & 26 & 11.5 & 46.2 & 61.5 & 46.2 & 76.9 & 11.5 & 30.8 & 65.4 & 42.3 & 26.9 \\
\hline 3220 & Comm equipment & 37 & 2.7 & 8.1 & 29.7 & 54.1 & 27.0 & 2.7 & 5.4 & 70.3 & 37.8 & 24.3 \\
\hline 3230 & TV/radio & 9 & 0.0 & 11.1 & 33.3 & 44.4 & 55.6 & 11.1 & 22.2 & 66.7 & 33.3 & 22.2 \\
\hline 3410 & Car/Truck & 9 & 11.1 & 22.2 & 33.3 & 44.4 & 55.6 & 11.1 & 22.2 & 33.3 & 44.4 & 22.2 \\
\hline 3430 & Auto Parts & 34 & 2.9 & 14.7 & 23.5 & 41.2 & 54.6 & 2.9 & 20.6 & 50.0 & 58.8 & 23.5 \\
\hline
\end{tabular}

Fields: Biology (BIO), Chemistry (CHEM), Physics (PHYS), Computer Science (COMPSC), Materials Science (MATSC), Medical and Health Science (MED), Chemical Engineering (CHEME), Electrical Engineering (EE), Mechanical Engineering (ME) and Mathematics (MATH).

Source: CMS survey reported in Cohen, Nelson and Walsh (2002).

Table A.3. Descriptive statistics: changes in university variables 1996 to 2001

\begin{tabular}{|c|c|c|c|c|c|}
\hline Variable & Mean & $\begin{array}{c}\text { Standard } \\
\text { Deviation }\end{array}$ & $\begin{array}{c}\text { Number of } \\
\text { postcode } \\
\text { areas with } \\
\text { zero } \\
\end{array}$ & $\begin{array}{c}\text { Minimum } \\
\text { in postcode } \\
\text { area }\end{array}$ & $\begin{array}{c}\text { Maximum } \\
\text { in postcode } \\
\text { area }\end{array}$ \\
\hline Dummy: Presence of university & 0.02 & 0.19 & 107 & -1 & 1 \\
\hline Number of universities & -0.05 & 0.37 & 96 & -1 & 1 \\
\hline Average university quality & 0.50 & 0.64 & 39 & -2.5 & 3 \\
\hline \multicolumn{6}{|l|}{ Rated 4 and below } \\
\hline Biology & -0.22 & 0.49 & 88 & -2 & 1 \\
\hline Chemistry & -0.22 & 0.57 & 92 & -3 & 0 \\
\hline Medicine & -0.49 & 1.37 & 75 & -6 & 1 \\
\hline Materials science & -0.06 & 0.39 & 97 & -2 & 1 \\
\hline Mechanical engineering & -0.16 & 0.63 & 91 & -4 & 1 \\
\hline Electrical engineering & -0.24 & 0.58 & 85 & -3 & 1 \\
\hline Computer science & -0.15 & 0.51 & 92 & -2 & 1 \\
\hline \multicolumn{6}{|l|}{ Rated 5 and $5 *$} \\
\hline Biology & 0.09 & 0.29 & 101 & 0 & 1 \\
\hline Chemistry & 0.07 & 0.26 & 103 & 0 & 1 \\
\hline Medicine & 0.40 & 1.30 & 93 & -1 & 9 \\
\hline Materials science & 0.00 & 0.13 & 109 & -1 & 1 \\
\hline Mechanical engineering & 0.06 & 0.34 & 101 & -1 & 2 \\
\hline Electrical engineering & 0.07 & 0.26 & 103 & 0 & 1 \\
\hline Computer science & 0.07 & 0.32 & 99 & -1 & 1 \\
\hline \multicolumn{6}{|l|}{ Control variables } \\
\hline Log (number research students in $5,5 *$ departments) & 0.02 & 0.13 & 62 & -0.56 & 0.82 \\
\hline Log (number research students in 1-4 departments) & 0.12 & 0.37 & 42 & -0.45 & 2.08 \\
\hline
\end{tabular}

Source: Authors' calculations using RAE data. 